\title{
Hydrochemical and Isotopic Composition of Tuzla Geothermal Field (Canakkale-Turkey) and its Environmental Impacts
}

\author{
Alper Baba , Galip Yuce , Ozan Deniz \& Didem Yasin Ugurluoglu
}

To cite this article: Alper Baba, Galip Yuce, Ozan Deniz \& Didem Yasin Ugurluoglu (2009) Hydrochemical and Isotopic Composition of Tuzla Geothermal Field (CanakkaleTurkey) and its Environmental Impacts, Environmental Forensics, 10:2, 144-161, DOI: 10.1080/15275920902873418

To link to this article: http://dx.doi.org/10.1080/15275920902873418

曲 Published online: 04 Jun 2009.

Submit your article to this journal $\widetilde{ }$

LII Article views: 145

View related articles $₫$

Citing articles: 6 View citing articles $\llbracket$ 


\title{
Hydrochemical and Isotopic Composition of Tuzla Geothermal Field (Canakkale-Turkey) and its Environmental Impacts
}

\author{
Alper Baba, ${ }^{1}$ Galip Yuce, ${ }^{2}$ Ozan Deniz, ${ }^{3}$ and Didem Yasin Ugurluoglu ${ }^{2}$ \\ ${ }^{1}$ Izmir Institute of Technology, Engineering Faculty, Department of Civil Engineering, 35430-Gulbahce, Urla, Izmir/Turkey \\ ${ }^{2}$ Eskisehir Osmangazi University, Engineering and Architecture Faculty, Geological Engineering Department, 26040, \\ Eskisehir-Turkey \\ ${ }^{3}$ Canakkale Onsekiz Mart University, Engineering and Architecture Faculty, Geological Engineering Department, 17100, \\ Canakkale-Turkey
}

\begin{abstract}
Tuzla is an active geothermal area located in northwestern Turkey, $80 \mathrm{~km}$ south of the city of Canakkale and $5 \mathrm{~km}$ from the Aegean Coast. Geothermal brine, deriving from this area, contains an abundance of $\mathrm{NaCl}$ and a water temperature of $173^{\circ} \mathrm{C}(\mathrm{T} 1$ well at 814 $m$ depth) is typically encountered. The aim of this study was to determine the hydrogeochemical properties of the geothermal brine using both chemical and isotopic data, and to investigate the origin of the geothermal brine in the Tuzla area and the environmental impacts of Tuzla Geothermal Field (TGF). Both geothermal brine and shallow groundwater in the area are of meteoric origin. Isotope results indicate that the hot saline waters (brine) in the Tuzla geothermal field originate from connate water along faults. As the saline water rises to the surface, it mixes with shallow groundwaters in various ratios. In addition, the high sodium $(\mathrm{Na})$ and chloride $(\mathrm{Cl})$ content in the Tuzla Stream, fed from the Tuzla geothermal brine during the dry season, cause an increase in sodium and chloride concentrations in the shallow groundwaters by infiltration into the aquifer. Moreover, salt accumulation on the surface is observed due to the uncontrolled artesian flow of geothermal brine, which adversely affects the salinity of shallow groundwater.
\end{abstract}

Keywords: Tuzla, geothermal fluid, hydrogeochemistry, oxygen-18, deuterium, tritium

Tuzla Geothermal Field (TGF) is located in northwestern Turkey, $80 \mathrm{~km}$ south of the city of Canakkale and $5 \mathrm{~km}$ from the Aegean Sea (Figure 1). Tuzla is an active geothermal area hosted by rhyolite lava and pyroclastic deposits. Geothermal brine is found in a shallow volcanic reservoir at a depth of between $330-350 \mathrm{~m}$ and a deep granite reservoir at a depth of 1,020 $\mathrm{m}$ (Vengosh et al., 2002). TGF is an interesting area in Turkey from the point of its temperature and dissolved ions in the water. At the surface, the waters reach temperatures between $32^{\circ} \mathrm{C}$ and $86^{\circ} \mathrm{C}$. The chloride concentration of Tuzla geothermal brine reaches $68,256 \mathrm{mg} / \mathrm{L}$, which is nearly twice the concentration of seawater, and is termed "brine" water. The total outflow of water from approximately 100 springs in the TGF field is estimated to be close to $50 \mathrm{~L} / \mathrm{s}$. The sodium and chloride concentrations reach up to $16,963 \mathrm{mg} / \mathrm{L}$ and $68,256 \mathrm{mg} / \mathrm{L}$, respectively.

Geothermal studies on the TGF have been ongoing since 1966. The general geological and volcanological characteristics have been studied by Samilgil (1966), Erdogan (unpublished data, 1966 MTA Report [Geothermal energy possibility of survey and tectonic mapping of Tuzla hot springs and surrounding]), Urgun (1971), Ongur (unpublished data, 1973 MTA Report

Received February 29, 2008; accepted December 22, 2008

Address correspondence to Galip Yuce, Eskisehir Osmangazi University, Engineering and Architecture Faculty, Geological Engineering Department, 26040, Eskisehir-Turkey. E-mail: gyuce@ogu.edu.tr
[Volcanology and geological report of Canakkale Tuzla geothermal area, Ankara]), and Alpan (1975). Geophysical surveys were carried out by Demirorer (unpublished data, 1971 MTA Report [Resistivity survey of Tuzla-Kestanbol hot springs and surrounding]) and Ekingen (1972). Ten thermal gradient wells were drilled from 50-100 m depth in 1974 based on the result of geological and geophysical surveys. Temperatures of up to $145^{\circ} \mathrm{C}$ were observed at $50 \mathrm{~m}$ depth in some of these wells, and, due to vigorous boiling, blowouts were observed (Karamanderesi and Ongur, 1974). Two deep exploration wells (with a depth range of $814-1020 \mathrm{~m}$ ) were drilled in 1982 and 1983. The reservoir depth is in the range of $333-553 \mathrm{~m}$ in volcanic rock with a temperature of $174^{\circ} \mathrm{C}$, a production rate of 130 tonnes $/ \mathrm{hr}$, and steam fraction of $13 \%$. The general characteristics of alteration in this field were described by Gevrek and Sener (1985). Hydrothermal alteration mineral assemblages indicate a geothermal fluid with temperatures of $150^{\circ} \mathrm{C}-220^{\circ} \mathrm{C}$ (Sener and Gevrek, 2000). Conformably, Mutlu and Gulec (1998) calculated the reservoir temperature of Tuzla to be between $187^{\circ} \mathrm{C}-212^{\circ} \mathrm{C}$ using different geothermometers (Table 1). The nature and origin of the thermal springs in the Tuzla area have been described by Mützenberg (1997). The environmental properties of the Tuzla geothermal field were described by Baba (2003), Baba and Ozcan (2004), and Baba et al. (2005). Tarcan (2005) emphasized that the Tuzla hot brine water has a high scaling tendency. According to previous studies, Tuzla geothermal brine originates from the dissolution of marine 


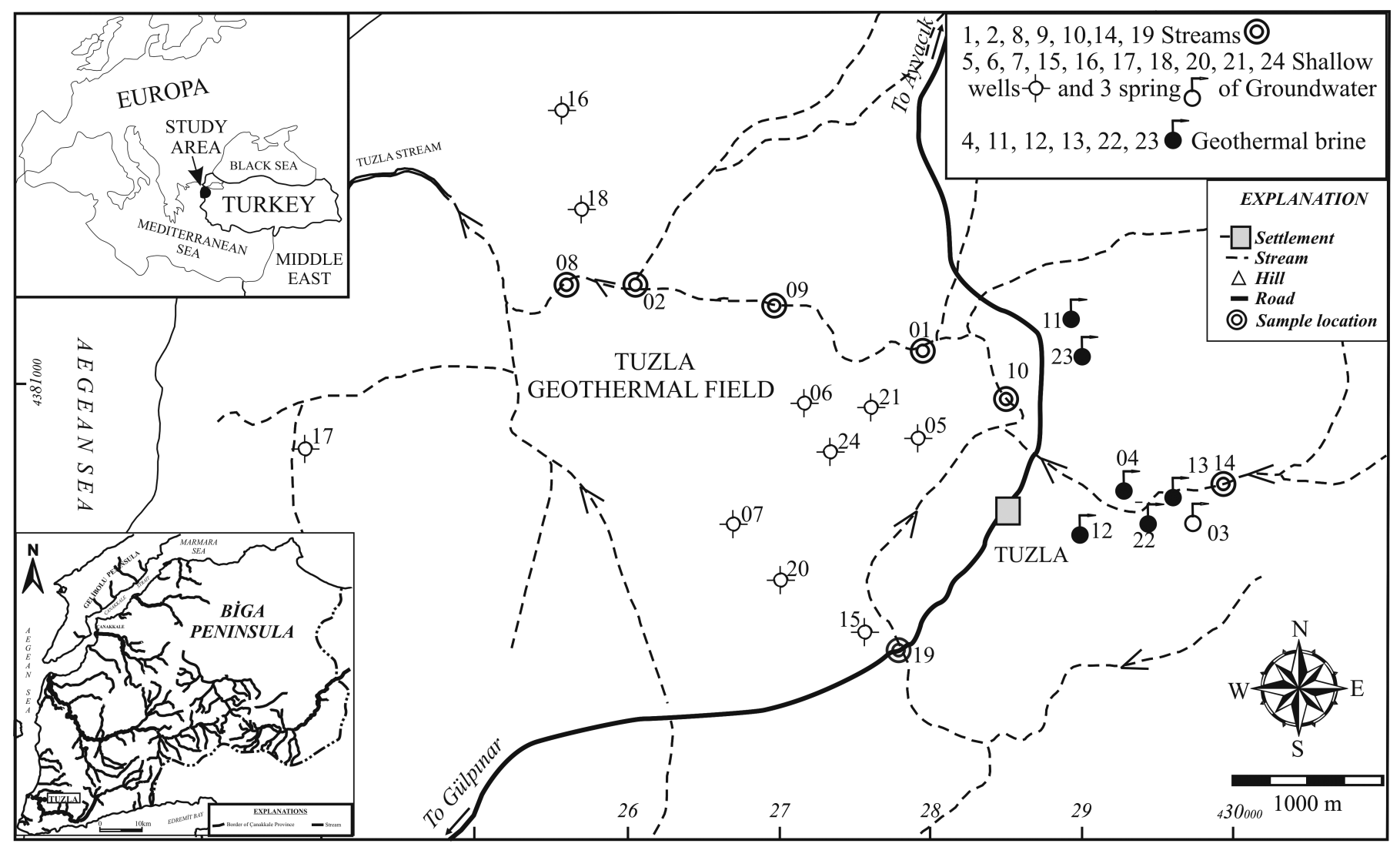

Figure 1. Location of Tuzla Geothermal Field.

evaporates and is formed by chemical alteration (dissolution of halite, dolomitization, reduction of sulphate, precipitation of anhydrite, digenetic reactions of silicates, $\mathrm{Ca}$ and $\mathrm{Na}$ ion exchange and reactions with organic matter), which generates the higher mineralization. Alternate models for the origin of the TGF include derivation from relics of evaporated seawater trapped in sediments (Balderer, 1997; Mützenberg, 1997), dissolution of Messinian evaporites (Vengosh et al., 2002) and trapped relict seawater within pore spaces in rocks (Yalcin, 2007).

Table 1. Geothermometry results for Tuzla geothermal brine waters

\begin{tabular}{|c|c|c|c|c|}
\hline Name & $\begin{array}{c}\text { Measured } \\
\text { temperature } \\
\left({ }^{\circ} \mathrm{C}\right)\end{array}$ & $\mathrm{Na} / \mathrm{K}$ & $\mathrm{K} / \mathrm{Mg}$ & $\mathrm{Na} / \mathrm{K} / \mathrm{Ca}$ \\
\hline Geothermal-13 & 77 & $182.4^{a}$ & $185.32^{a}$ & $212.47^{b}$ \\
\hline Geothermal-23 & 60.7 & $232.59^{a}$ & $209.94^{a}$ & $231.34^{b}$ \\
\hline $\mathrm{T} 1^{*}$ & 174 & $\begin{array}{l}183^{c} \\
213^{d}\end{array}$ & & $218^{b}$ \\
\hline $\mathrm{T} 2^{*}$ & 168 & $\begin{array}{l}239^{c} \\
256^{d}\end{array}$ & & $254^{b}$ \\
\hline $\mathrm{T} 1^{* *}$ & 171 & $212^{a}$ & $187^{a}$ & $205^{b}$ \\
\hline $\mathrm{T} 1^{* * *}$ & 174 & 225 & & 230 \\
\hline
\end{tabular}

$\left({ }^{a}\right.$ Gigenbach (1988), ${ }^{b}$ Fournier ve Truesdell (1973), ${ }^{c}$ Truesdell (1976), ${ }^{d}$ Fourner (1979), ${ }^{*}$ Calculated by Tarcan, 2005, ${ }^{* *}$ Calculated by Mutlu and Güleç, 1998, ${ }^{* * *}$ Calculated by Yalcin, 2007).
Metamorphic rocks and granite intrusion as the basement rocks in the TGF are not exposed in the study area. However, the basement has been identified from drilling as a granite intrusion at $702 \mathrm{~m}$ depth (Sener and Gevrek, 2000). The basement rocks are overlain by Tertiary strata comprising pyroclastic rocks, rhyolite tuff, sedimentary units (gravel, sandstone, claystone and marl) and rhyodacite lava (Figure 2). These Tertiary strata are highly altered and covered by Quaternary sediments and alluvium (General Directorate of Mineral Exploration and Research [MTA], 1997; Samilgil, 1983). The currently active thermal regime is associated with Late Miocene volcanism in the TGF (Sener and Gevrek, 2000). Generally, the major geologic structures in the TGF are recognized to be N-S and NW-SE trending fault systems (Figure 2). The N-S trending fault system is situated at the boundary of Neogene sediments and Quaternary alluvium. Along the N-S trending fault system, many geothermal springs have developed. The major faults trending NW-SE along the western and southern slope of Tuzla Tepe Ridge are normal faults.

Three mechanisms threaten the quality of shallow groundwater in the area: 1) upconing of old connate hypersaline geothermal brine; 2) sea-water intrusion from the Aegean Sea; and 3) halite dissolution at the surface and seepage into the shallow aquifer. Most residents of the Tuzla village abstract shallow groundwater from alluvium for irrigation purposes. Therefore, it will be beneficial to understand the effects of the 

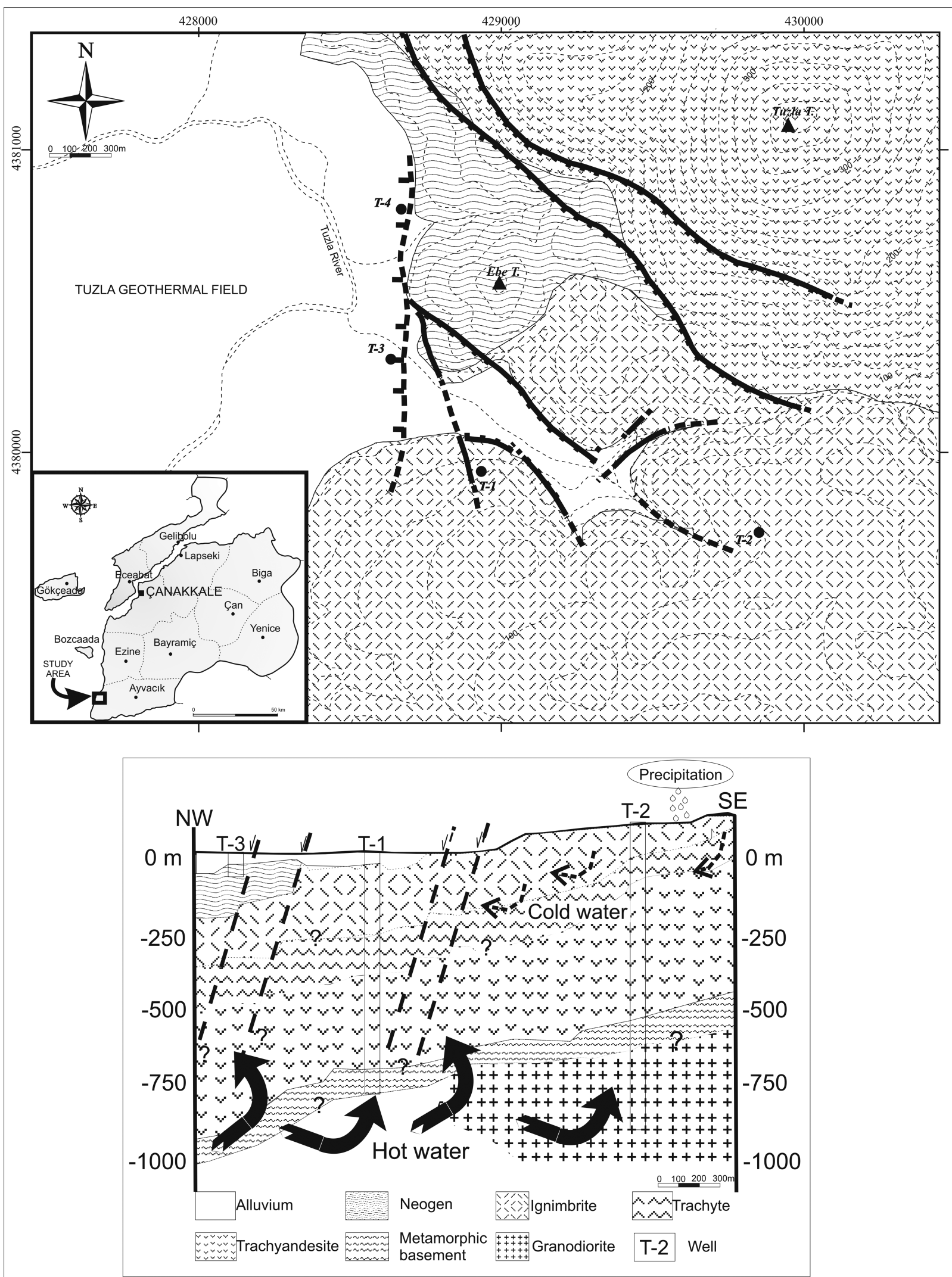

Figure 2. Simplified geological and sampling map of Tuzla Geothermal Field (Modified from Karamanderesi, 1986). 
geothermal brine on the shallow groundwater, especially the relationship between dissolution of the surficial salt crust and injection of hypersaline geothermal fluid from the deep source. In this respect, the aim of this paper is to clarify the hydrogeochemistry of the TGF and to determine its environmental effects.

\section{Methods}

Four sampling campaigns were carried out in August and December 2003 and March and June 2004. Sixty-nine water samples were taken from geothermal springs, and groundwaters from shallow wells and surface waters. The surface water samples were collected from various points where they mixed with geothermal brine. The sampling locations are shown in Figure 1. The concentrations of major ions ( $\mathrm{Na}, \mathrm{Ca}, \mathrm{Mg}, \mathrm{HCO}_{3}, \mathrm{Cl}$, and $\mathrm{SO}_{4}$ ), trace elements (As, $\mathrm{Sr}, \mathrm{Fe}$ and $\mathrm{Mn}$ ), and environmental isotopes (oxygen-18, deuterium, and tritium) were determined on water samples taken from seven surface water samples $(1,2$, $8,9,10,14$ and 19), eleven shallow groundwater samples $(3,5$, $6,7,15,16,17,18,20,21$ and 24) and six geothermal spring samples $(4,11,12,13,22$ and 23) in the study area. Only one sample, collected in June 2004, was analyzed from location 23 as this spring has only recently been identified.

For major ions and for trace metal analyses, 1-L plastic bottles were used. To prevent the complex formation of trace elements with oxygen, samples were filtered by $0.45-\mu \mathrm{m}$ filter paper and acidified to $\mathrm{pH} \leq 2$ condition by adding $0.5 \mathrm{~N} \mathrm{HNO}_{3}$. The trace metal analyses were measured by ICP-AES. Electrical Conductivity (EC), temperature $\left({ }^{\circ} \mathrm{C}\right)$ and $\mathrm{pH}$ values were measured in-situ with a multi-parameter instrument. Chemical analyses were carried out using the ICP-AES for $\mathrm{Na}, \mathrm{K}$, $\mathrm{Ca}$, and $\mathrm{Mg}$ while $\mathrm{Cl}$ and $\mathrm{HCO}_{3}$ values were determined by titration method at the laboratories of Canakkale Onsekiz Mart University (COMU) (Canakkale, Turkey). The concentration of deuterium (D) and oxygen-18 isotopes $\left({ }^{18} \mathrm{O}\right)$ in the samples were determined in the laboratories of the Technical Research and Quality Control Department of the State Hydraulic Works (DSI) in Ankara. For this purpose, mass spectrometry was used with an overall precision of $1 \%$ and $0.1 \%$ for deuterium and oxygen-18, respectively. These values are expressed conventionally in delta notation as per mil deviation from the VSMOW (Vienna Standard Mean Ocean Water) (Verhagen et al., 1991). Tritium was analyzed in the laboratory of Karst Research and Application Centre at Hacettepe University with a liquid scintillation counter (LSC) after electrolytic enrichment of the water samples with an error of \pm 0.8 Tritium Units (TU).

\section{Results and Discussion}

\section{Hydrogeochemical Evaluation}

Analytical results for the geothermal brine waters, shallow groundwaters, and surface waters of Tuzla area are given in
Tables $2 \mathrm{a}, 2 \mathrm{~b}$, and $2 \mathrm{c}$, respectively. Results from the sampling campaign of March 2004 have not been considered because these samples have elevated electro neutrality (Apello and Postma, 1992) and a reaction error of $>5 \%$ (Freeze and Cherry, 1979). Thus, instead of 69 water samples, 47 water samples were evaluated.

Sodium and chloride are the dominant ions in the geothermal brine waters of the Tuzla region (Table 2a) while calcium and bicarbonate are the dominant ions in the shallow groundwater. Surface waters in the region are characterized by sodium and chloride ions, remarkably high during dry periods. Thus, the chemical composition of surface waters is mainly controlled by the discharge of hyper-saline geothermal brine.

\section{Geothermal brine}

The emergence of geothermal brine can be the result of an extensional tectonic regime where the lithosphere is thinner and uplift has occurred due to isostasy (Keisuke, 1978). Active seismicity in the region allows liquid at depth to rise more easily. The ascending brine is to some extent cooled and diluted by mixing with groundwater.

Analytical results for the geothermal brine samples indicate contrasting compositions during wet and dry periods. During dry periods, geothermal brine contains relatively elevated concentrations of $\mathrm{Cl}$ and $\mathrm{Na}$ compared with wet periods. This may result from $\mathrm{Ca} / \mathrm{Na}$ ion exchange by albitization of plagioclase and formation of Na-rich clays in the geothermal aquifer (Kloppmann et al., 2001). The higher $\mathrm{NaCl}$ concentration seen in dry periods is possibly due to either subsurface evaporation of geothermal brine or to no dilution effect from surface water. Furthermore, an increase in $\mathrm{CO}_{2}$ during the dry period may cause the $\mathrm{pH}$ to decrease and an enrichment of $\mathrm{Cl}$ (Kaszuba et al., 2003; 2005). The outflowing of $\mathrm{NaCl}$ rich thermal brine is an indication of present hydrothermal activity (Mützenberg, 1997). During the dry period, the $\mathrm{Ca}$ content of the geothermal brine decreases since part of the $\mathrm{CO}_{2}$ is released from the geothermal brine and $\mathrm{CaHCO}_{3}$ is precipitated. In another regard, the low $\mathrm{Mg}$ content in geothermal brine slightly increases during wet periods, possibly due to its mixing with surface waters by rapid recharge to depth.

The solubility of $\mathrm{Na}$ slightly decreases while $\mathrm{Cl}$ solubility is maintained during dry periods, because concentrations of $\mathrm{Na}$ and $\mathrm{Cl}$ increase subsequently until saturation with halite occurs, then the $\mathrm{Cl}$ content continues to increase with increasing evaporation (Apello and Postma, 1992), which takes place in the subsurface. For this reason, $\mathrm{Na}$ concentrations may not increase while $\mathrm{Cl}$ does increase in the dry period geothermal brine of the Tuzla area. Moreover, $\mathrm{Na}$ is not conservative in water-rock reactions as is chloride. Plots of $\mathrm{Na}$ versus $\mathrm{B}$ and $\mathrm{Cl}$ versus $\mathrm{B}$ (Figure $3 \mathrm{a}$ and $3 \mathrm{~b}$ ) indicate that the geothermal brine waters (samples $4,11,12,13,23)$ can readily be distinguished with their much higher $\mathrm{Na}, \mathrm{Cl}$ and $\mathrm{B}$ values from shallow groundwaters (samples $5,16,18)$. In addition, the arsenic content of Tuzla geothermal brine is elevated probably due to water-rock interactions at depth under the influence of solution from an arsenopyrite 


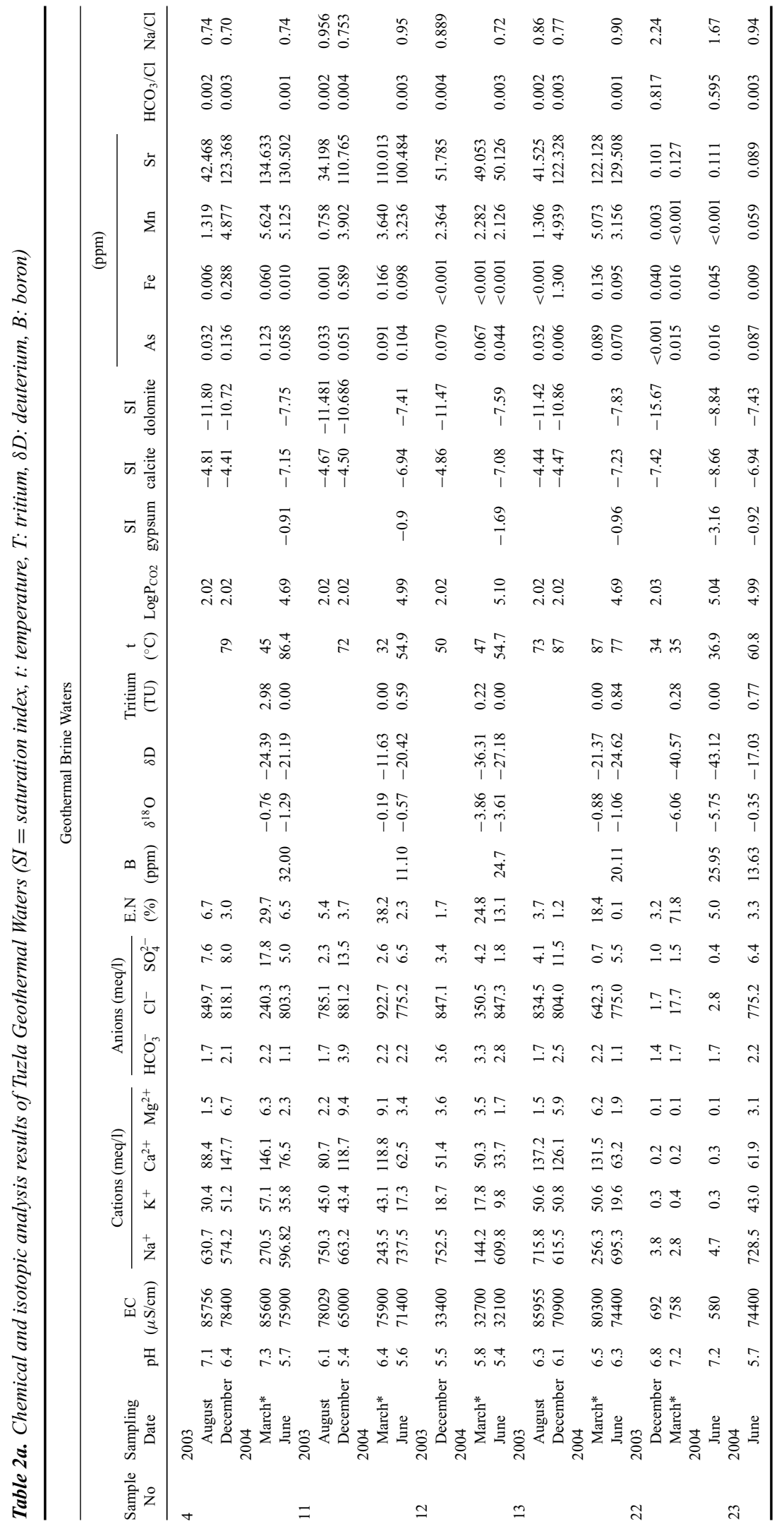




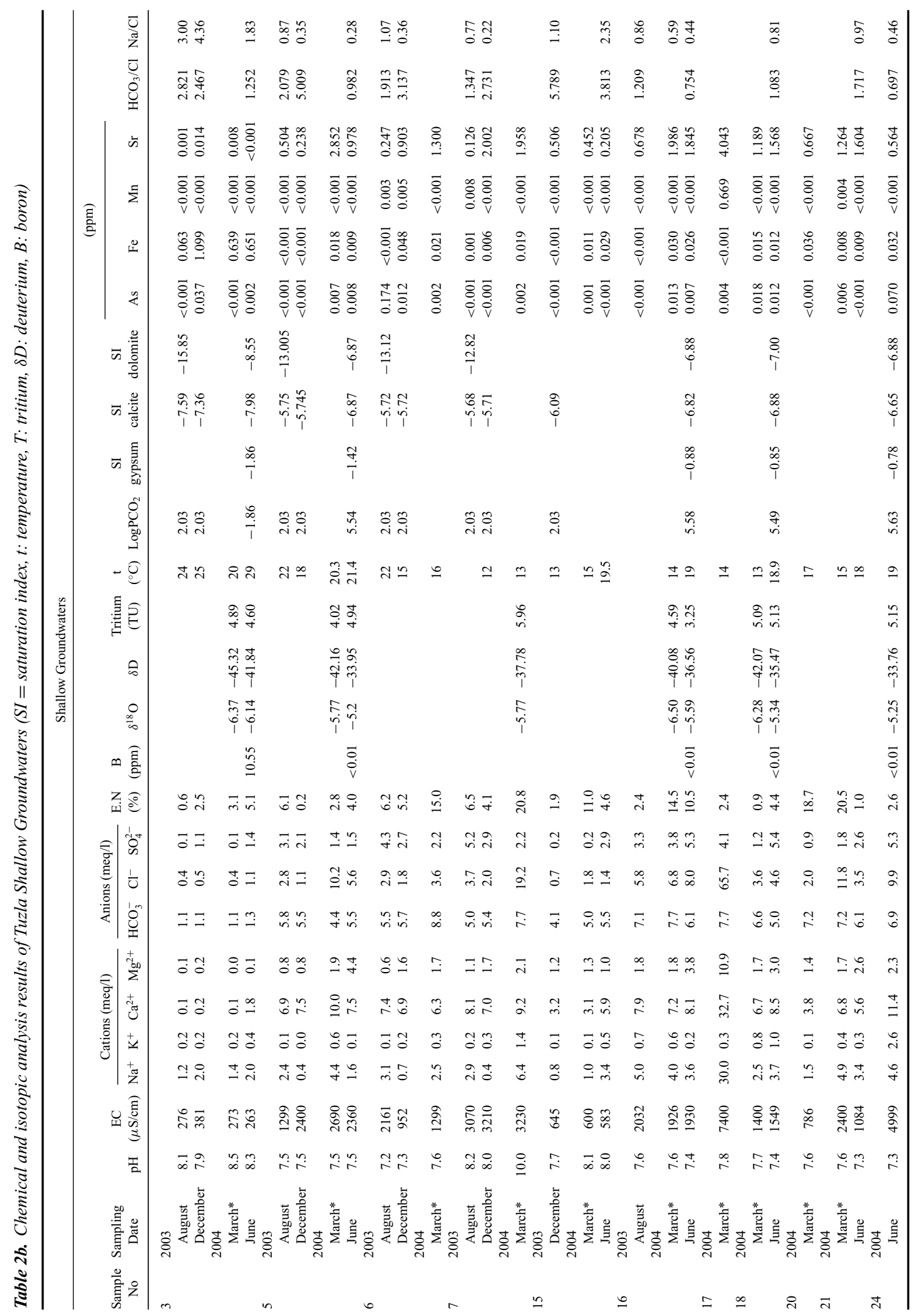




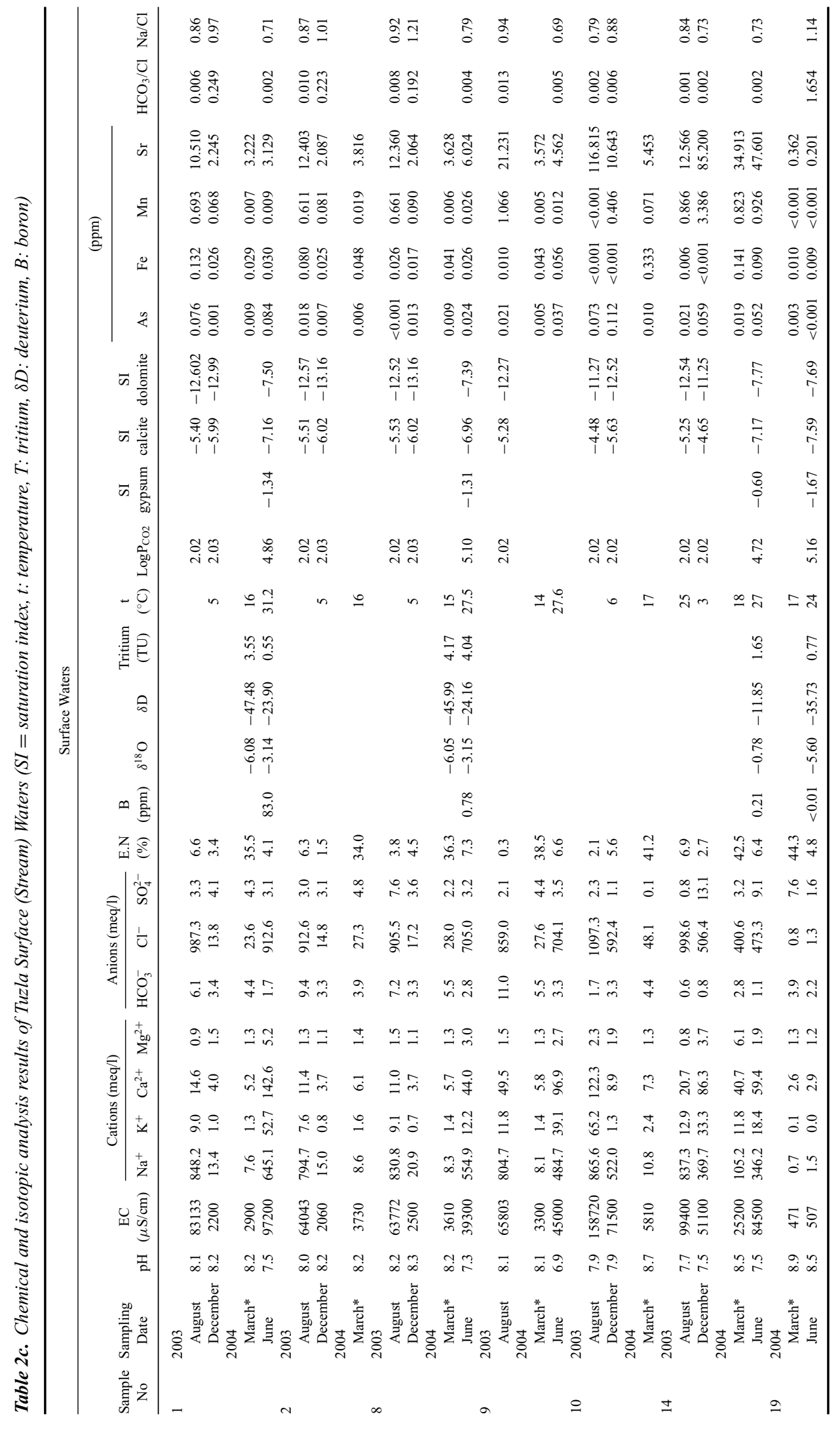


and pyrite rock assemblage. Consequently, considerable arsenic enrichment in saline $\mathrm{Na}-\mathrm{Cl}$ type geothermal brine takes place in Tuzla geothermal brine. On the other hand, slight arsenic content can also be traced in the shallow groundwaters while arsenic in geothermal brine is adsorbed onto iron-hydroxides, and then it can easily decline in the shallow groundwater environment by oxidation.

According to the Piper diagram in Figure 4a, the geothermal brine (except for sample 22) is in $\mathrm{NaCl}$ facies (in the same facies as seawater) in both dry and wet periods. Sample 22 is of the $\mathrm{Na} \mathrm{Cl}, \mathrm{HCO}_{3}$ water type due to steam-heated groundwater because it contains comparatively more bicarbonate than other geothermal brine waters while having a higher temperature than other shallow groundwaters. Accordingly, sample 22 contains a considerably lower total ion concentration (cations and anions), very low $\mathrm{Na}-\mathrm{Cl}$, and the lowest "As" content of geothermal brine.

\section{Surface waters}

As the Tuzla Stream crosses the area with thermal (brine) spring occurrences, it is clear that its water presents a mixture of shallow surface water, shallow cold groundwater and the water of the upwelling thermal brine. Therefore, according to the chemical constituents, its composition will change according the mixing proportions depending on whether it is the dry or wet season (base-flow influence).

Except for sample 19, the salinity effect of hyper-saline geothermal brine on the stream clearly plots with the $\mathrm{NaCl}$ facies of a traditional Paper diagram (Figure 4b), particularly in dry periods. However, stream water sample 19 plots on the mixed water type with $\mathrm{CaHCO}_{3}$ dominant due to abundant replenishment from shallow groundwater (Baba et al., 2007) and its position being distant from the geothermal springs.

Overall, the Tuzla Stream samples show increased salinity during dry periods due to a greater relative input from geothermal brine waters compared to rainwater and shallow groundwater (Table 2c). The high boron and chloride contents of samples from the Tuzla Stream reflect an abundant source of geothermal brine throughout the dry period.

\section{Shallow groundwaters}

Seasonal trends in the composition of shallow groundwater are variable. Shallow groundwaters are generally $\mathrm{CaHCO}_{3}$ type waters in the wet period while in the dry period, they change into the mixed water type associated with $\mathrm{NaCl}$ and $\mathrm{CaSO}_{4}$ (Figure $4 c) . \mathrm{Na} / \mathrm{Cl}$ ratios are below 1 in some of the brackish shallow groundwater (samples 5, 6, 7, 16). Recent halite $(\mathrm{NaCl})$ precipitation as a surface crust (on top of the soil) formed by discharge of geothermal brine in the dry period causes deterioration of the shallow groundwater quality (Table $2 \mathrm{~b}$ ) by means of washing down into the shallow aquifer units (samples 5, 6, 7, 16, 18, 21, 24).

Groundwater sample 24 (Figure 4c) records an elevated conductivity value that indicates the influence of geothermal brine. Conformingly, the highest total ion concentration, relatively high arsenic content (the highest is sample 6) (Table 2b), and the lowest $(\mathrm{Na}+\mathrm{Ca}) / \mathrm{Cl}$ value for shallow groundwater is recorded by sample 24 (Figure 5).

Almost all groundwater samples (mainly $\mathrm{Na}$ and $\mathrm{Cl}$ contents of samples 5, 6, 7, 15, and 16 increased from June or August to December) shifted to mixed water type under influence of geothermal brine during the dry period (Table 2a). For example, sample 3 is characterized as a $\mathrm{NaHCO}_{3}$ water type during wet periods and as a mixed water type during dry periods, due to the influence of thermal brine with high chloride content (Figure 4c). Sample 3 is representative of shallow groundwater with lower electrical conductivity (EC), temperature, and ion concentrations. It is suggested that the higher chloride values of shallow groundwater samples in dry periods are due to the seepage of $\mathrm{NaCl}$ salts accumulated at the surface from geothermal springs in the area. The increase in sodium and chloride values in shallow groundwater would lead to degradation of soil structure and properties with respect to permeability, porosity, and agricultural attributes. The shallow groundwater is utilized by farmers for irrigation purposes and most complain about the deterioration of water quality due to the influence of geothermal brine on both shallow groundwater and the surface water of the Tuzla Stream. Shallow groundwaters are influenced by geothermal brine in ratios between $1.5 \%$ and $9 \%$ based on their chloride values. However, there is no remarkable negative effect of irrigation return water on the shallow aquifer, since irrigation is not widely performed in the area. The main salinity problem of shallow groundwater derives from the seepage of geothermal brine in the area. In the case of the wells which were drilled by the MTA and some springs, the unsealed evaporation basin probably caused the vertical infiltration of geothermal brine into the shallow plain aquifer. Approximately $50 \mathrm{~m}$ below the well, the mineralized water discharges at the surface as a small spring. As a consequence of the high salt content of the geothermal component, evaporation process and low discharge rate of the spring, the surrounding dark-grey to black soil is covered by white salt crust with an aerial extension of ca. 1 $\mathrm{km}^{2}$ (Baba et al., 2005). As previously mentioned, the TGF is located near recent volcanic activity areas. The slightly acidic $\mathrm{NaCl}$ Tuzla brine flows out of places where the permeability is high (i.e. fault and fracture zones). Eventually, the geothermal brine diffuses into shallower aquifers, which changes its fluid chemistry.

According to the solution indices (SI), all waters are undersaturated with respect to calcite, dolomite, and gypsum (Figure 6). If the geothermal water is in equilibrium with considered minerals at a given temperature, all SI converge to zero at that temperature. If the geothermal waters (brine) mix with water of low salinity (i.e. shallow groundwater), then all SI are shifted downward into the under-saturation field (Marini). As can be seen in Figure 6, waters are relatively saturated with respect to gypsum, compared with calcite and dolomite, and this saturation is partly maintained in the dry period because the dissolution of gypsum occurs more readily than calcite and dolomite since a higher amount of $\mathrm{NaCl}$ exists in the water (Apello and Postma, 


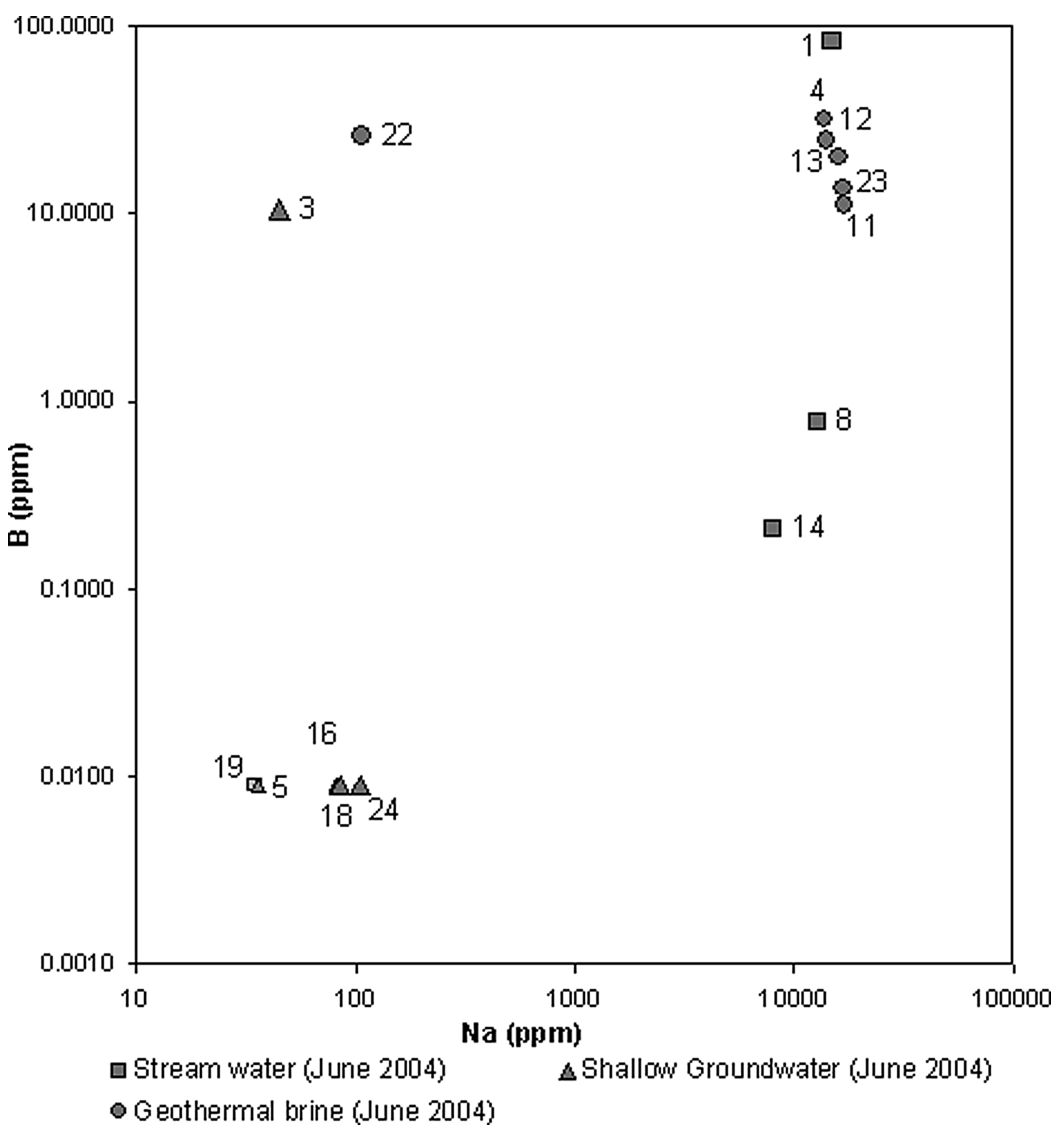

Figure 3a. Na-B diagram.

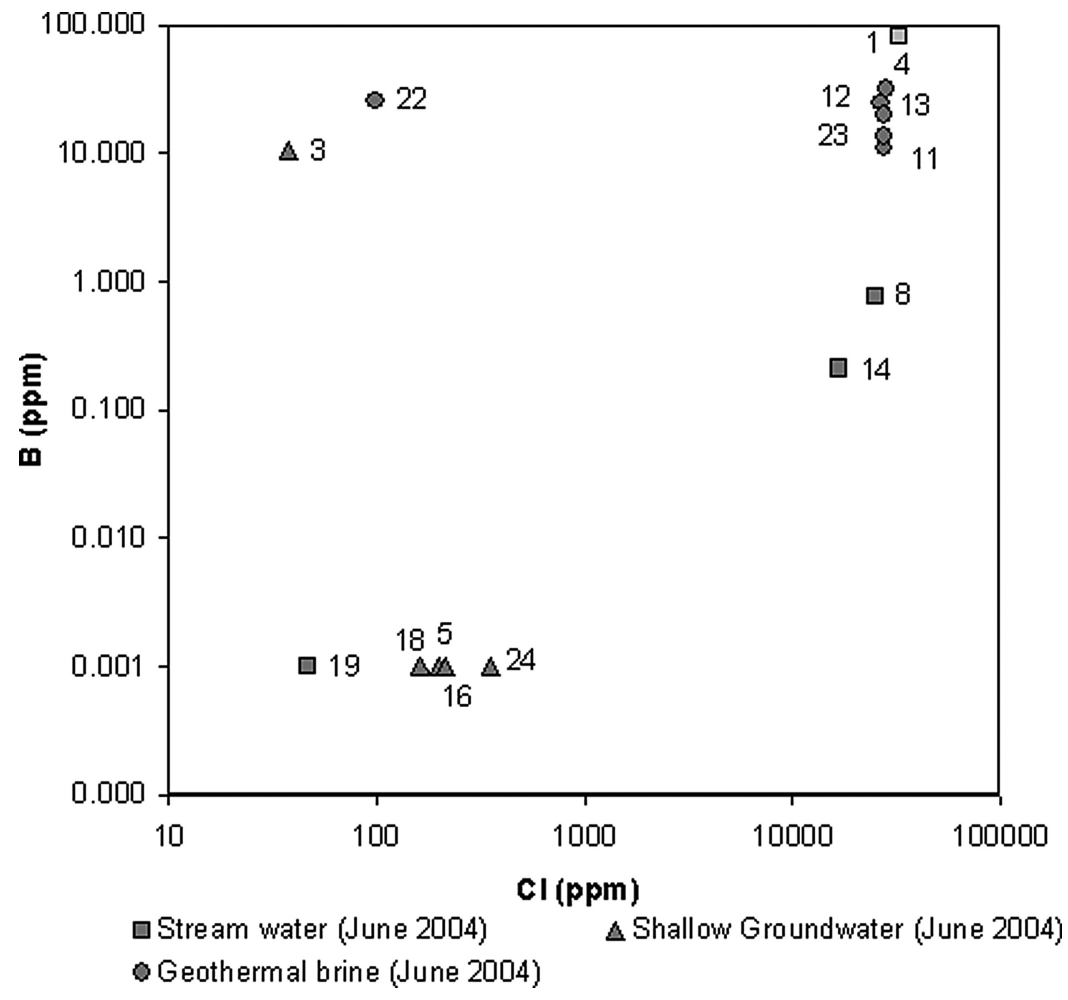

Figure 3b. Cl-B diagram. 


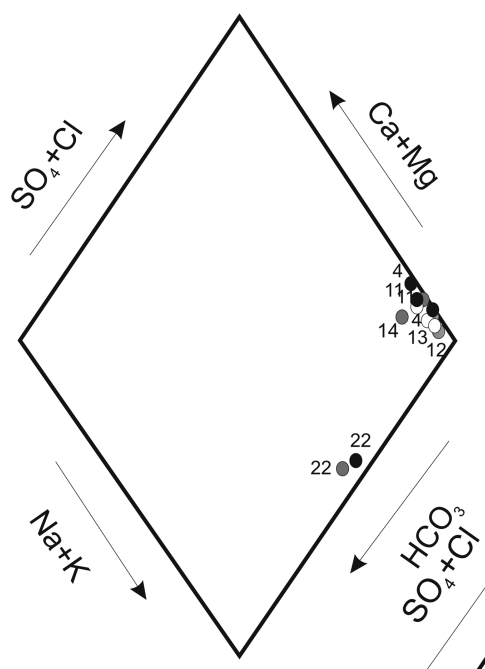

a)

\section{a) Geothermal brine (Augt 2003)}

- Geothermal brine (Dec. 2003)

- Geothermal brine (June 2004)

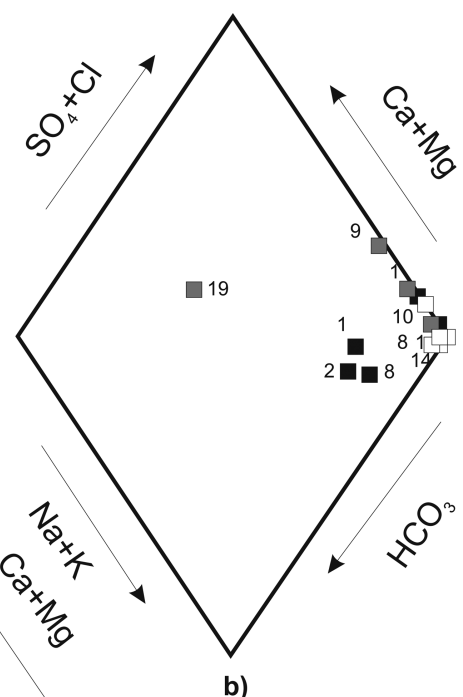

b)

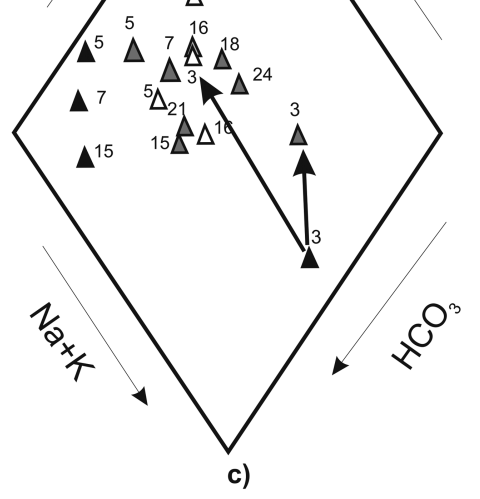

b) $\square$ Stream water (Augt 2003)

- Stream water (Dec. 2003)

- Stream water (June 2004) c) $\triangle$ S.Groundwater (Augt 2003)

$\Delta$ S.Groundwater (Dec. 2003)

$\Delta$ S.Groundwater (June 2004)

Figure 4. Chemical analysis of water in the study area plotted on Piper diagrams.

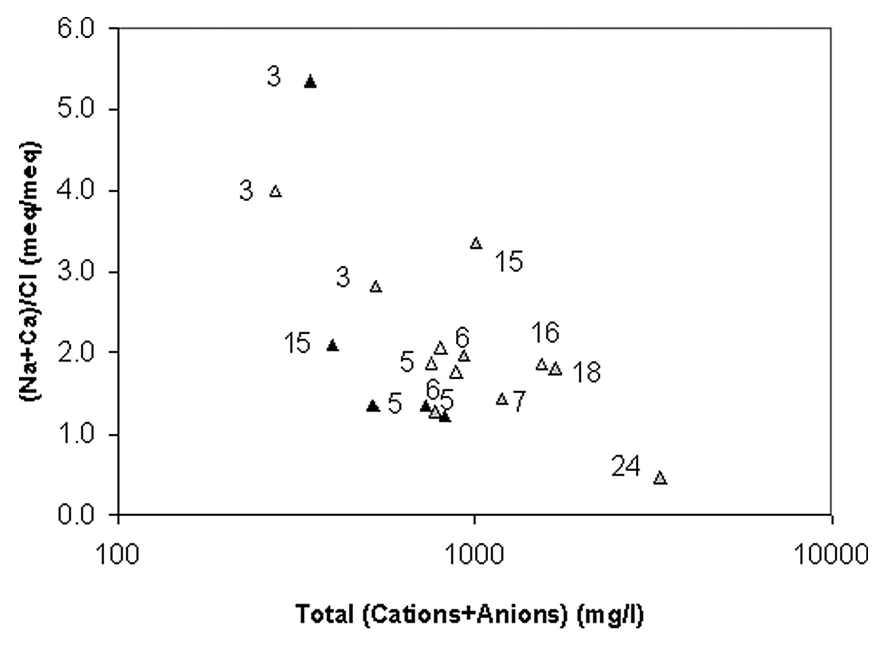

$\Delta S$.Groundwater (August 2003)

A S.Groundwater (Dec. 2003)

$\triangle$ S.Groundwater (June 2004)

Figure 5. $(\mathrm{Na}+\mathrm{Ca}) / \mathrm{Cl}$-Total (Cations+Anions) diagram of the shallow groundwaters.
1992). As $\mathrm{NaCl}$ increases the ionic strength of the solution, concentrations generally increase (Kehew, 2001), but calcite dissolution rates generally decrease with increasing brine concentration (Gledhill, 2005).

A further evaluation of the cation-anion distribution can be completed using the ternary diagrams of Giggenbach (1988) (Figure $7 \mathrm{a}, 7 \mathrm{~b}, 7 \mathrm{c}$ ). The ternary diagram is based on hydrothermal systems where the compositions of deep high-temperature fluids (full equilibrium line) are the result of isochemical recrystallization. Samples from deep geothermal waters generally plot on the full equilibrium curve (mature water) and their temperatures are slightly higher than those physically measured in these waters (Marini). However, most of the shallow groundwaters in Tuzla appear to be mixed waters (Figure 7a), Ca dominated (Figure $7 \mathrm{~b}$ ), and highly immature waters, indicating that these waters have not attained equilibrium (Figure 7c). The surface waters plot on mixed (Figure 7a), Na dominated (7b), and immature waters while geothermal brine falls on the corner of mature waters (7a), Na dominated (7b), and partially equilibrated waters, which indicates attainment of partial equilibrium with respect to chemical composition. The geothermal brine in Tuzla is a 


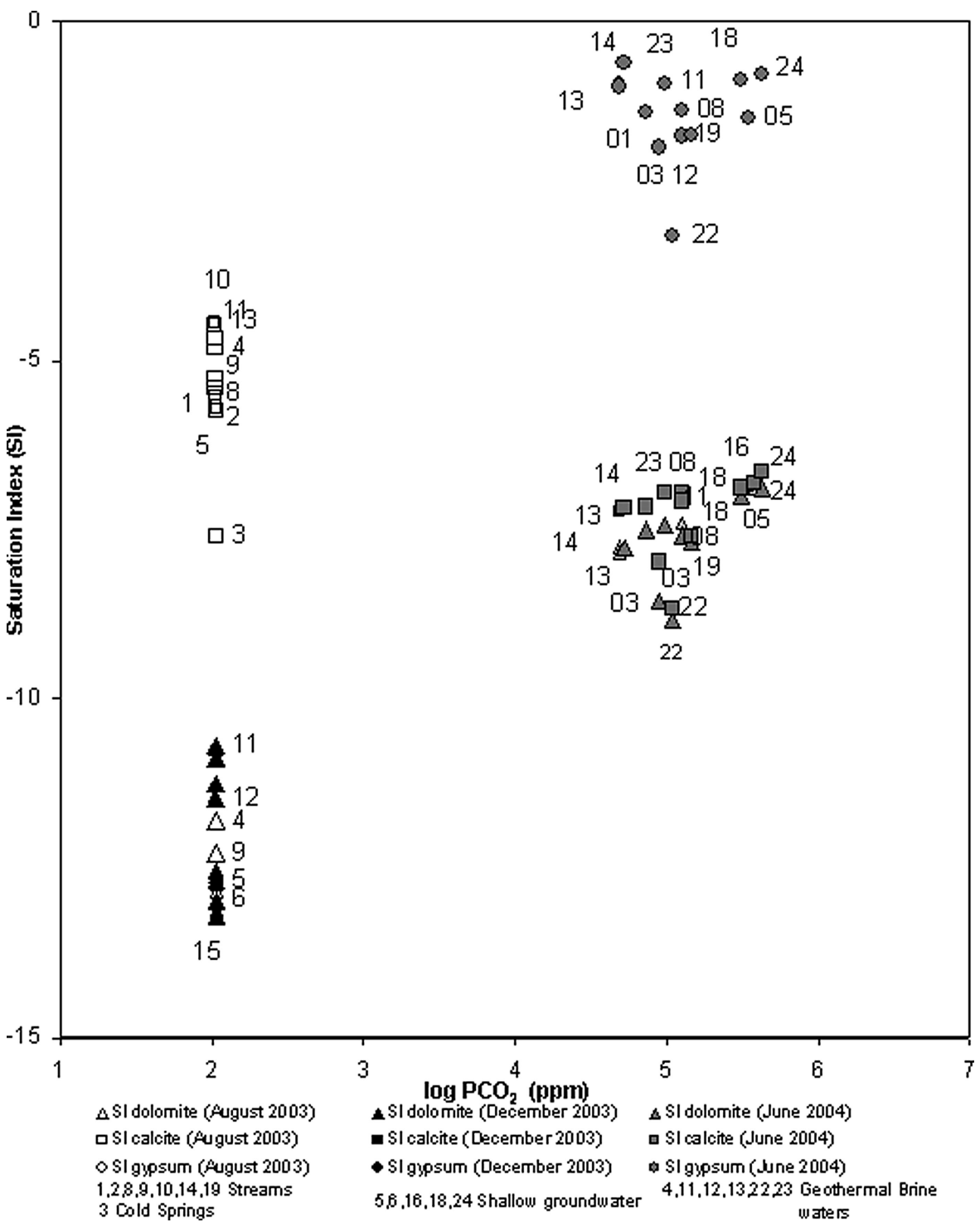

Figure 6. Chemical equilibrium of samples on saturation diagram showing relative mineral saturations.

$\mathrm{Cl}$ dominated geothermal brine (Figure 7a) (except sample 22) while the shallow groundwaters are in the mixed area (Figure 7a). The $\mathrm{HCO}_{3} / \mathrm{Cl}$ ratios of geothermal brine are much lower than those of shallow groundwater, which is expected (Table $2 \mathrm{a}$ and $2 \mathrm{~b}$ ). The dilution process by shallow groundwaters in geothermal brine having a short circulation plays an important role that is reflected in the $\mathrm{Na} / 1000-\mathrm{K} / 100-\mathrm{Mg}^{0.5}$ ternary diagram (Figure 7c). Apart from samples 12 and 22, all other geothermal brine waters plot as partially equilibrated waters, namely 4, 11, 13 and 23. Based on their location on Figure 7c, samples 12 and 22 are presumed to be steam-heated shallow groundwater and mixed water with shallow groundwater, respectively.

Briefly, three processes play an important role in the salinization of soil and degradation of shallow groundwater quality in the Tuzla region: 1) albitization (the production of albite as a secondary mineral in the rock) of plagioclase in the deep- seated geothermal aquifer resulting in an increase in $\mathrm{NaCl}$ and $\mathrm{CO}_{2}$, and decrease in Ca concentration; 2) a deep geothermal brine influence either into shallow groundwater or discharging to surface water; and 3 ) halite crystallization.

\section{Trace Elements and Environmental Impact}

The black and reddish color of geothermal brine samples $(4,11$, 12, 13) with high As, Mn, and Fe content (except for sample 12 because it partially mixes with shallow groundwater that may cause a decrease in Fe concentration due to precipitation by oxidative condition) (Figure 8) is attributed to the dissolution of ferromanganese minerals within Late Miocene sediments. The high trace metal content in the hot-saline waters of the TGF results from rapid evolution of anoxic conditions in brines (Drever, $1997)$ and reduction of the sulphite $\left(\mathrm{SO}_{3}\right)$ formed by reactions with trace elements, followed by release of trace elements during 

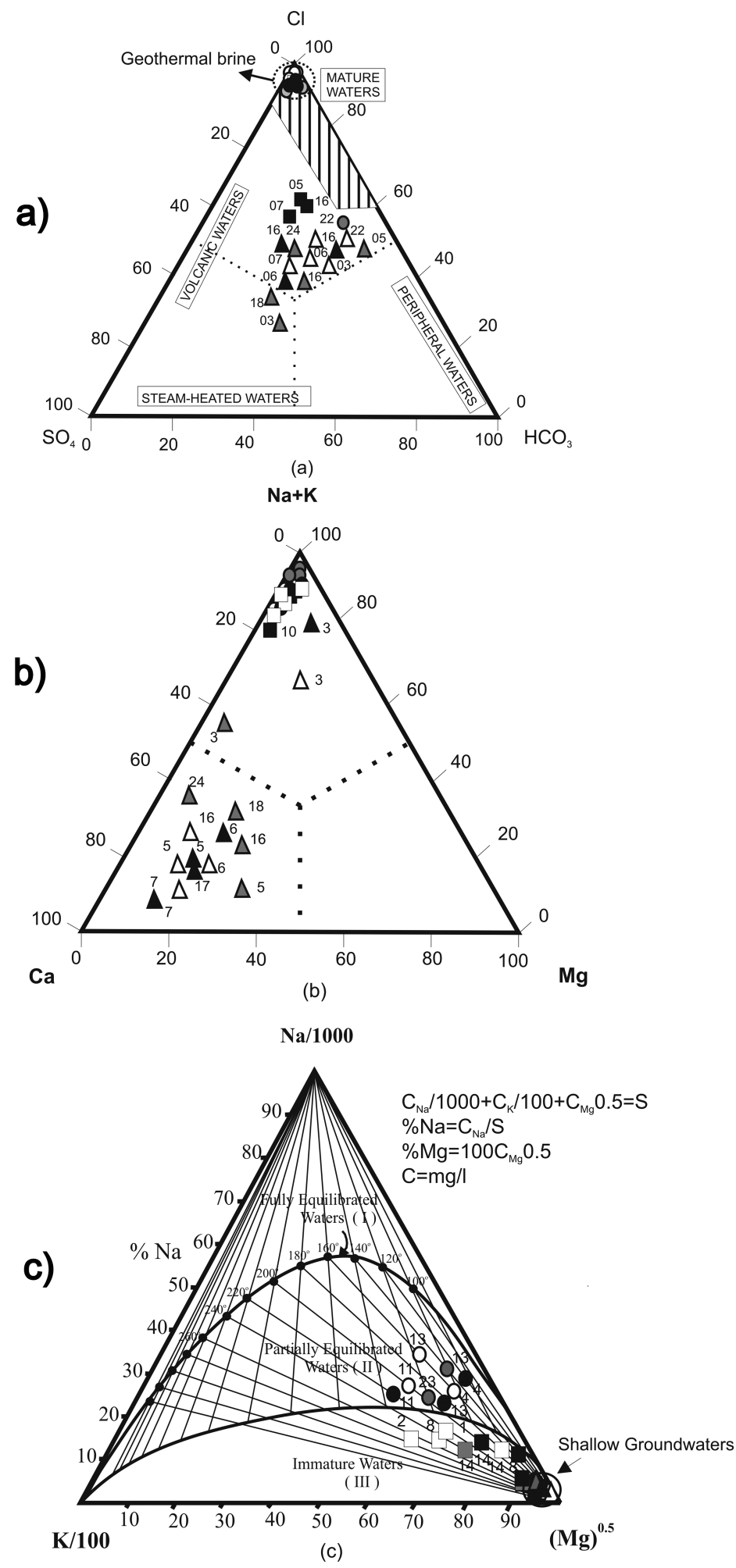

Geothermal brine (August 2003) - Geothermal brine (Dec. 2003) - Geothermal brine (June 2004) $\square$ Stream water (August 2003)

- Stream water (Dec. 2003) - Stream water (June 2004) $\triangle$ S.Groundwater (August 2003) $\Delta$ S.Groundwater (Dec. 2003) $\Delta$ S.Groundwater (June 2004)

Figure 7. Chemical analysis of waters in study area plotted on Ternary-Giggenbach (1988) diagrams. a) Cl-SO4-HCO3. b) (Na+K)-Ca-Mg. c) Na/1000$\mathrm{K} / 100-(\mathrm{Mg})^{0.5}$. 


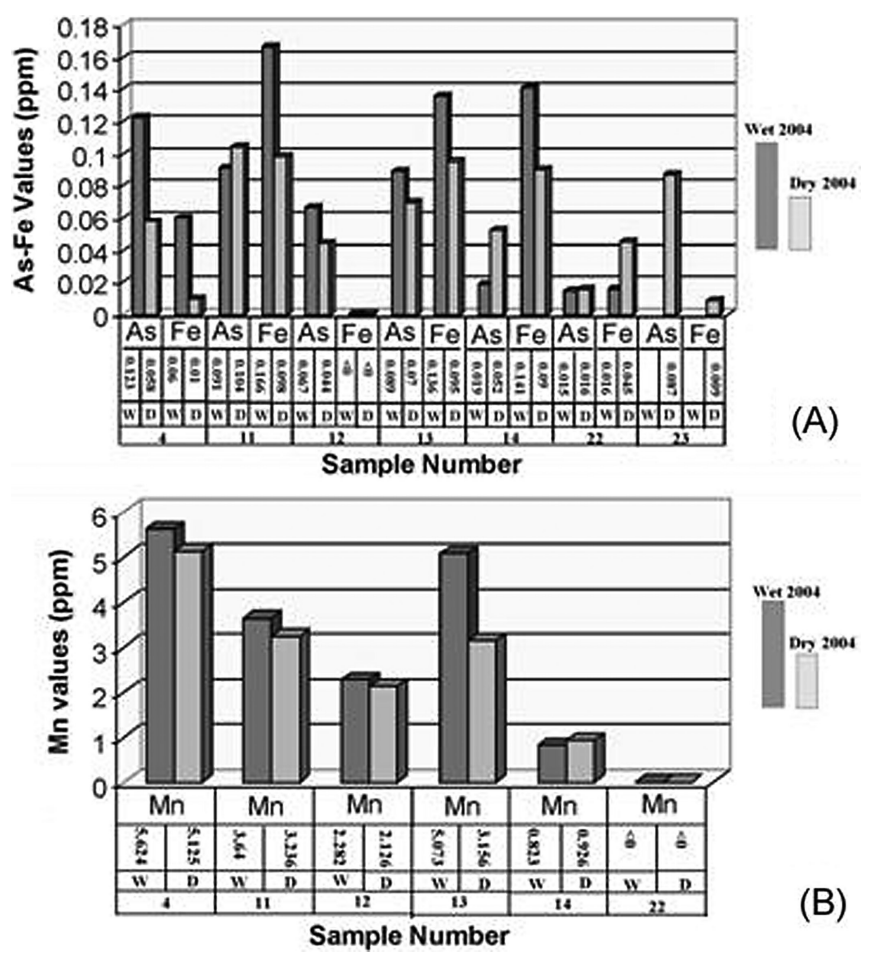

Figure 8. Arsenic, iron, manganese and strontium contents of geothermal brine waters in Tuzla Region.

oxidation of the metal sulfides by bacterial activities. For this reason the concentration of As, Fe, and Mn in the geothermal brine recorded in March 2004 (wet period) is similar and/or slightly higher than in June 2004 (dry period) due to mixing with shallow groundwater (having oxidizing condition) which provides easy dissolution of As in an aquatic environment (Figure 8). The As content may also be elevated due to dissolution of As in rhyolite tuff (Stauffer and Thompson, 1984) that outcrops in the study area.

Sr content of groundwater is a good indicator of seawater intrusion, as evident from the high $\mathrm{Sr}$ concentration in shallow well no. 17 (Table 2b), located near the coastline. The high electrical conductivity (EC), chloride, and sodium contents of sample 17 support the seawater encroachment interpretation. It is considered that seawater intrusion is a relatively recent event due to its $\mathrm{CaCl}_{2}$ composition, because, when seawater influences a coastal fresh water aquifer, sodium in seawater is occupied by soil, and calcium is released by the fresh water aquifer. The water quality then changes from $\mathrm{NaCl}$ (coming from seawater) to $\mathrm{CaCl}_{2}$ (Apello and Postma, 1992). Accordingly, sample 17 from shallow groundwater, originally $\mathrm{CaHCO}_{3}$, shifted to $\mathrm{CaCl}_{2}$ composition as a result of seawater encroachment.

The EC, sodium, chloride, and temperature values of the waters of Tuzla Stream (samples 1, 2, 8, 10) (Table 2c) increase during the dry period (August 2003) due to discharge of geothermal fluid into the Tuzla Stream. It is thought that salts, including trace metal salts, precipitate during the dry period and that surface water with higher mineralization due to leaching of the superficial salt crusts infiltrate the shallow groundwater.

\section{Geothermometers}

Chemical analyses of geothermal fluids can be used to estimate subsurface reservoir temperature. Chemical geothermometers depend on the water-mineral equilibrium and give the last equilibration temperature for the reservoir (Nicholson, 1993). Several geothermometry techniques have been developed to predict reservoir temperatures in geothermal systems (Fournier and Truesdell, 1973; Fournier, 1979; Fournier and Potter, 1982; Arnórsson et al., 1983; Giggenbach et al., 1983; Giggenbach, 1988). All of these techniques are based on the assumption that temperature dependent water-mineral equilibrium is attained in the reservoir. Solute geothermometry techniques were applied to the hot waters from springs in the Tuzla geothermal field. The cation geothermometers applied to water samples 13 and 23 for June 2004 include Na-K, K-Mg (Giggenbach, 1988) and $\mathrm{Na}-\mathrm{K}-\mathrm{Ca}$ (Fournier and Trusedell, 1973). The results of geothermometer applications (Table 1) indicate some estimations for subsurface reservoir temperature that range from $182.4^{\circ} \mathrm{C}$ to $232.59^{\circ} \mathrm{C}$. These results also are consistent with previous results calculated by Mutlu and Gulec, 1998; Tarcan, 2005, and Yalcin, 2007. Temperatures of up to $145^{\circ} \mathrm{C}$ were observed at $50-\mathrm{m}$ depth in some of wells in the TGF. According to MTA drilling (well T1 at $814 \mathrm{~m}$ depth, Fig. 2), the reservoir depth is in the range of $333-553 \mathrm{~m}$ in volcanic rock with a temperature of $173^{\circ} \mathrm{C}$.

\section{Isotope Analyses Results and Discussion}

The $\delta^{18} \mathrm{O}$ values of the geothermal brine (Table $2 \mathrm{a}$ ) vary between -0.19 and $-3.86 \%$ (except sample 22 because it is steam-heated groundwater) versus Standard Mean Ocean Water (SMOW) (Verhagen et al., 1991) and the $\delta \mathrm{D}$ values vary between -11.63 and $-36.31 \%$ (except sample 22 ) versus SMOW. The $\delta^{18} \mathrm{O}$ content of geothermal brine is enriched up to -0.19 , while $\delta \mathrm{D}$ is depleted to -21.37 indicating a high $\delta^{18} \mathrm{O}$ shift, which is due to rock-water interaction at higher temperatures. The $\delta^{18} \mathrm{O}$ values of the shallow groundwaters (Table $2 b$ ) vary between -5.20 and $-6.50 \%$ and the $\delta \mathrm{D}$ values vary between -33.95 and $-45.32 \%$. Hence, the most saline geothermal brine is enriched in respect to the shallow groundwater by as much as $6.31 \%$ in $\delta^{18} \mathrm{O}$ and $41.46 \%$ in $\delta \mathrm{D}$. Tritium values ranged from 0 to $2.98 \mathrm{TU}$ for geothermal brine, and from 3.25 to $5.96 \mathrm{TU}$ for shallow groundwaters. The three samples between the circles of dry period and brine $(12,01$ and 08$)$ are the result of mixing of shallow groundwater and brine.

Detailed information about geothermal brine, shallow groundwaters, and surface waters is given in Tables $2 \mathrm{a}, 2 \mathrm{~b}$, and $2 \mathrm{c}$. The high tritium $(\mathrm{T})$ and low deuterium $(\delta \mathrm{D})$ values at $\mathrm{T}-\delta \mathrm{D}$ plotted in Figure 9 represent rapid circulation in the shallow groundwater system while geothermal brine having higher $\delta \mathrm{D}$ and lower $\mathrm{T}$ values implies a longer and deeper circulation of 


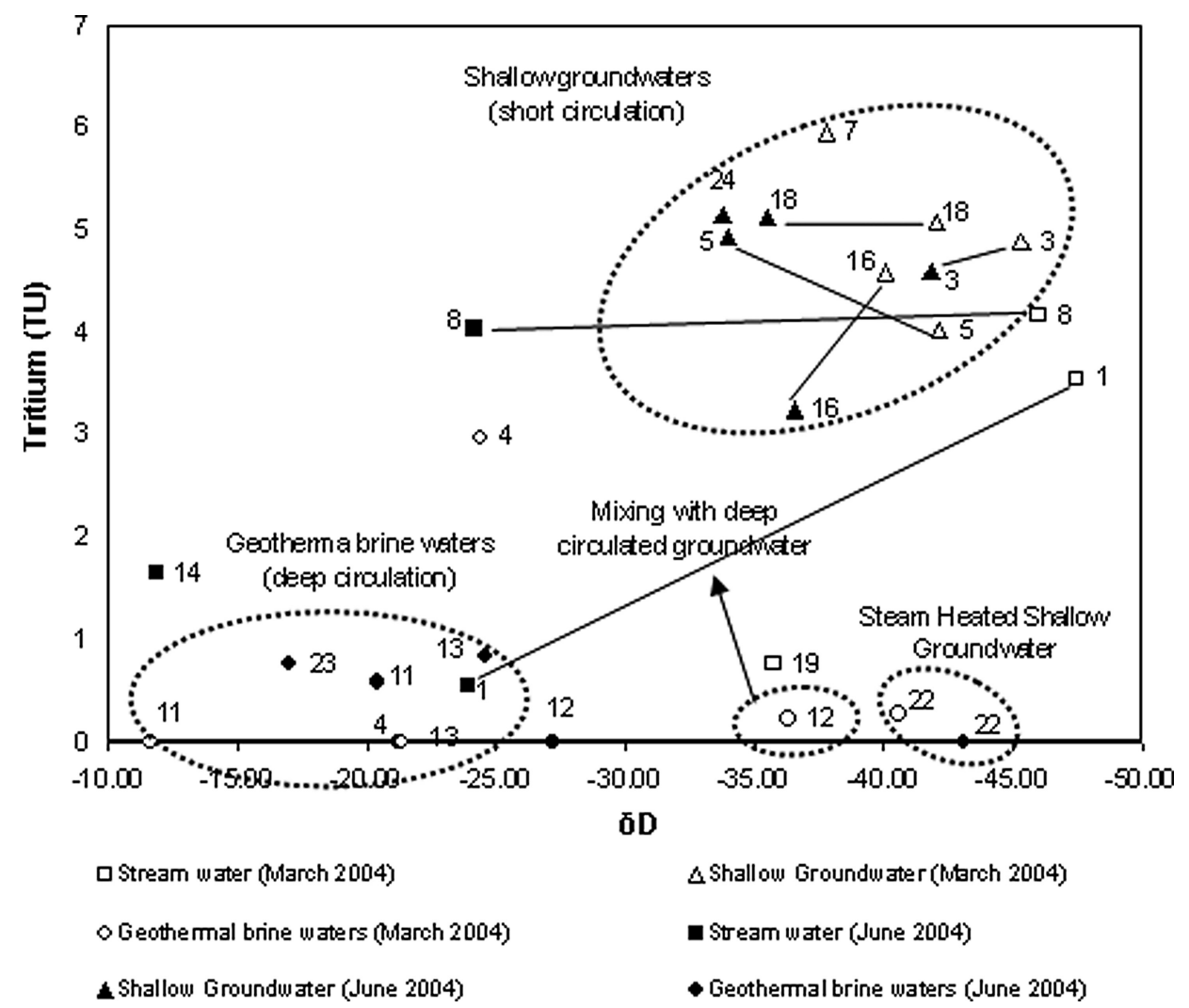

Figure 9. Deutrium ( $\delta$ D)-Tritium (TU) diagram (open symbols represent March 2004 samples, closed symbols represent June 2004 samples).

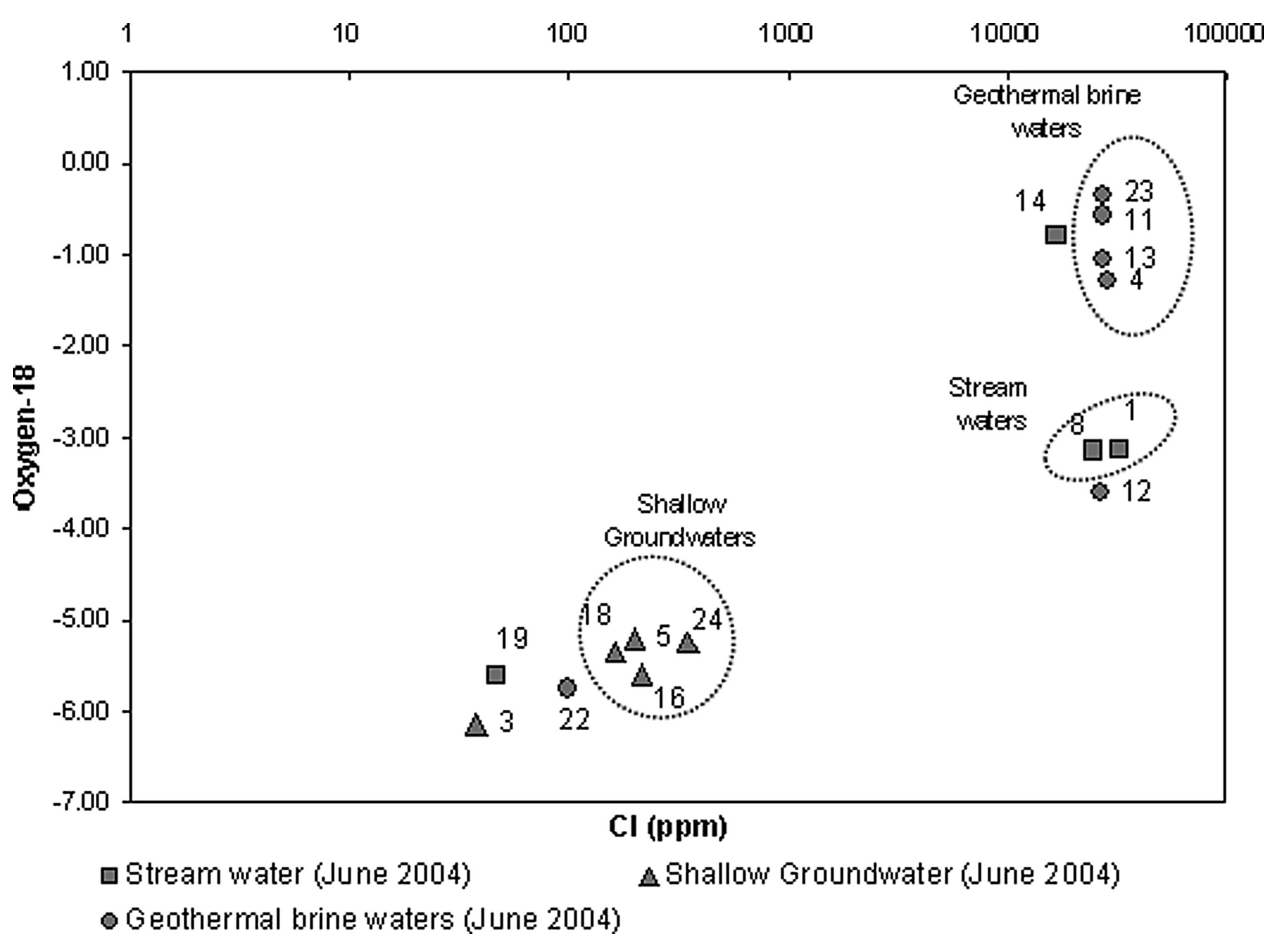

Figure 10. Chloride- $\delta^{18} \mathrm{O}$ diagram. 


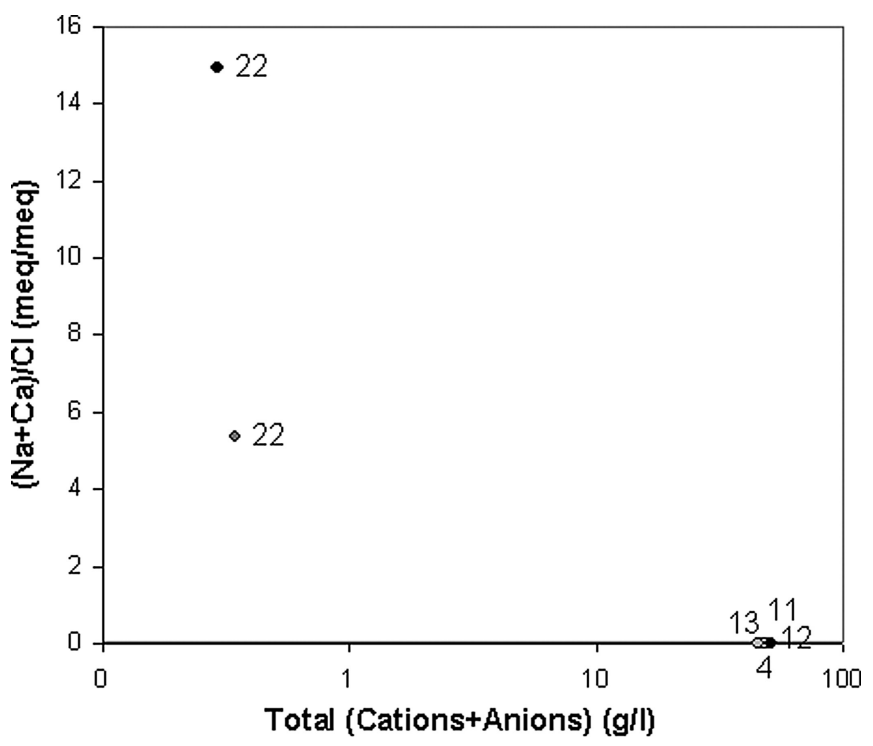

- Geothermal brine (August 2003)

- Geothermal brine (June 2004)

Figure 11. $(\mathrm{Na}+\mathrm{Ca}) / \mathrm{Cl}$-Total (Cations+Anions) diagram of geothermal brine waters. groundwater. Geothermal spring no. 12 is mixing with geothermal brine and deep circulated groundwaters with lower tritium and relatively depleted oxygen-18 and deuterium values. Samples 4 and 12 were able to maintain their original properties in the dry period with lower tritium and more positive deuterium values, i.e. they arise from a deep-seated geothermal aquifer and groundwater sources, respectively.

Sample 22, with low temperature and conductivity, represents steam heated shallow groundwater having relatively depleted stable isotope values compared with other geothermal brine waters (Figure 9 and Figure 10). As shown in Figure 10, the concentration of cations and anions shows large differences between the rainy and dry seasons and the $\delta^{18} \mathrm{O}-\mathrm{Cl}$ relationship can be employed to distinguish seawater and halite-dissolved solution (Ma et al., 2007). The relatively higher $\mathrm{HCO}_{3} / \mathrm{Cl}$ ratio (Table 2a) and the elevated $(\mathrm{Na}+\mathrm{Ca}) / \mathrm{Cl}$ ratios with the lowest total ions (Figure 11) of sample 22 also support this idea. The lower tritium value of sample 22 indicates older groundwater age. The chloride and stable isotope values of stream waters (1, $8,14)$ are increased by overflowing of geothermal brine, especially in the dry period (Figure 10 and Figure 12). This increase can be traced in major ion contents. Geothermal sample-22 plots

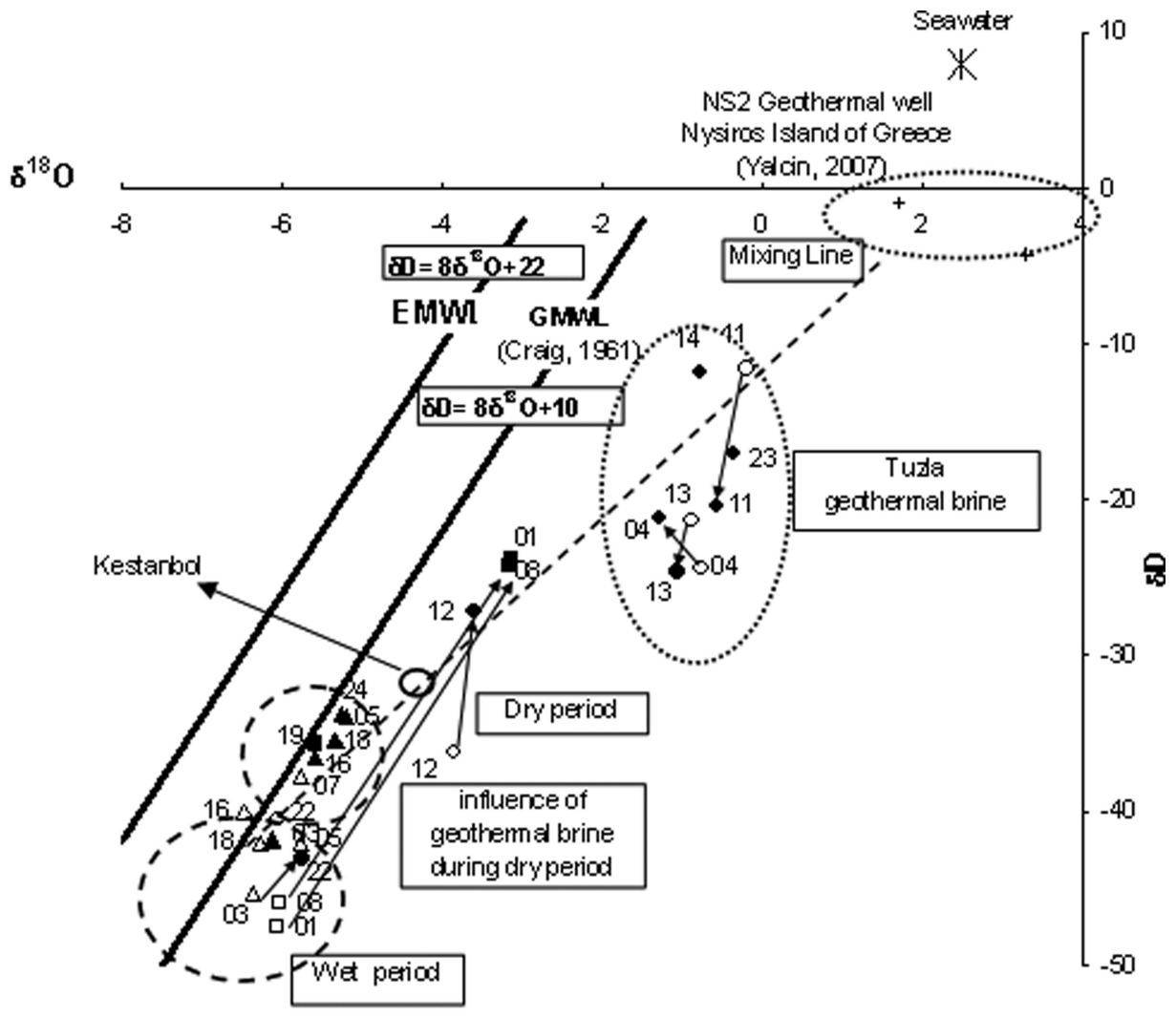

\footnotetext{
O Geothermal brine (March 2004)

Figure 12. Oxygen-18 $\left(\delta^{18} \mathrm{O}\right)$-Deuterium $(\delta \mathrm{D})$ diagram (EMWL: Eastern Mediterranean Water Line, GMWL: Global Meteoric Water Line). 
with shallow groundwaters, indicating either shallow circulation or mixing with shallow aquifer waters. There seems to be no effect of enrichment due to evaporation in the oxygen-18 and deuterium plot (Figure 12). The Tuzla Stream waters (samples 1 and 8 ) are surface waters recharged by precipitations at high altitudes of the study area in the wet period. When these locations are influenced by discharging of geothermal brine, they become of a similar salinity to geothermal brine with higher oxygen-18 and deuterium values. For this reason, waters taken from the Tuzla stream show abrupt change due to the effect of geothermal brine discharging during the dry period (Arrow shows change due to geothermal influence during dry and wet periods in Figure 12). The $\delta^{18} \mathrm{O}$ values of geothermal brine water 4,11 , and 13 show no remarkable seasonal changes except for their $\delta \mathrm{D}$ values, probably due to exchange with clays or hydrocarbons (International Atomic Energy Agency [IAEA], 1981). In fact, the low tritium and high $\delta^{18} \mathrm{O}$ and $\delta \mathrm{D}$ values of these geothermal brine waters (samples $4,11,13$ ) show that they have a long residence time and are deep-originated geothermal brine.

In Figure 12, most of the shallow groundwaters in the wet season fall below GMWL (Craig, 1961). This setting can be explained by mixing with geothermal brine, which has caused a shift in the isotopic composition of shallow groundwater samples that were originally on GMWL or another local meteoric water line. The higher electrical conductivity (EC) values of shallow groundwater also support this idea. Stable isotope values of shallow groundwaters in the dry period are relatively more positive than those of the wet period due to a decrease in the contribution of winter precipitation into the shallow aquifer. According to Figure 12, geothermal brine is enriched in $\delta^{18} \mathrm{O}$ because water-rock interaction takes place when the temperature is $>150^{\circ} \mathrm{C}$ in the aquifer system (Hoefs, 1987).

Geothermal brine waters are situated in a completely different cluster (Figure 12) from the shallow groundwater, which have lower $\delta \mathrm{D}$ and elevated T values varying from $4 \mathrm{TU}$ to $6 \mathrm{TU}$ compared with the geothermal waters with higher $\delta \mathrm{D}$ and lower tritium. The isotopic values of Kestanbol (10 km north of Tuzla) and Tuzla have similar salinity values to Nysiros brine shown in Figure 12. Yalcin (2007) gives the most probable explanation for the origin of discharging brine in Tuzla and Kestanbol areas as deep-seated hot fossil seawater resulting from dilution and cooling during uprising by infiltrating meteoric water. Accordingly, the $\mathrm{Br} / \mathrm{Cl}$ ratio of the Tuzla brine is rather lower than that of the recent seawater (Mützenberg et al., 1992). Furthermore, Yalcin (2007) points out that Tuzla geothermal brine is stretched to the values of Nysiros brine by dilution of deep-seated hot brine. This explanation is shown in Figure 12 by the dashed line. Thus, the origin of Tuzla geothermal brine is deep brine water entrapped in pore spaces of the rocks. The present day isotopic composition of Mediterranean Sea Water is $\delta^{18} \mathrm{O}=+2.5, \delta^{2} \mathrm{H}=+8$ and the origin of Nysiros brine is a mixture of deep thermal fluid and shallow cold groundwater. The addition of groundwater input is less in Nysiros.

As the geothermal brine moves to the surface, it is probably cooled by either mixing with surface water or conductive

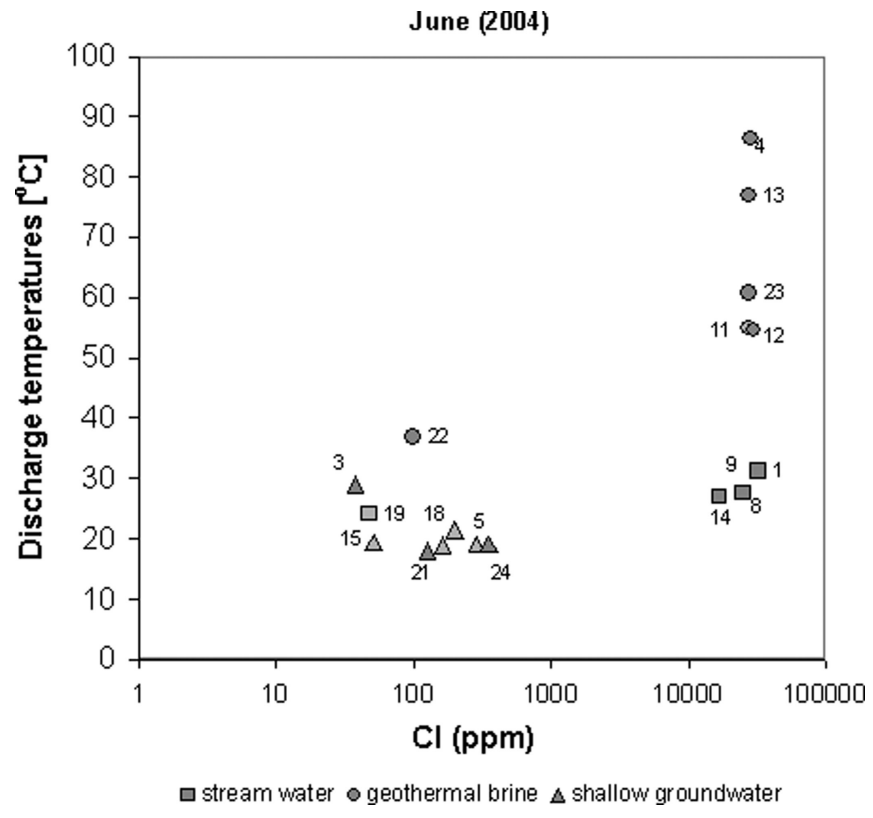

Figure 13. Relationship between discharge temperatures and chloride contents.

cooling (i.e. during ascent of liquid water with conductive heat loss). The hydrogen composition is not changed, as there is no other hydrogen-containing mineral available (Figure 13). All geothermal brine waters in the TGF (except sample 22, steamheated water) have similar $\mathrm{Cl}$-contents against the descending discharge temperatures.

The d-excess $\left(=\delta \mathrm{D}-8 \delta^{18} \mathrm{O}\right)$ of the shallow groundwaters varies between $5-10 \%$, reflecting no substantial postprecipitation change of isotope composition (Figure 14). The shallow groundwater with d-excess $>5 \%$ and lower $\delta^{18} \mathrm{O}<$ $-5 \%$ are representative of low evaporation and higher permeability (Gupta et al., 2005; Istvan et al., 2006). The higher tritium values are also in good consistence with this setting. Thus, the lower d-excess and higher $\delta^{18} \mathrm{O}$ values imply high evaporation and low permeability or a long residence time.

The stable isotope data indicate that the infiltration of evaporated return irrigation water is somewhat responsible for the occurrence of subsurface salinity in the shallow groundwater. Since the Tuzla plain has a topographically flat area where salt accumulation is easily formed due to flowing out from the geothermal brine springs and salts are leached to the subsurface during significant recharge periods. However, these salts can reach the shallow groundwater in a few months. This is confirmed by the elevated salt contents of the samples taken during the dry season. Although there is no clear evidence to identify the main source of the salinization in the shallow groundwater, as either upward movement of geothermal brine or surficial leakage into the shallow aquifer, the low temperature of shallow groundwater supports the second alternative.

The tritium contents of shallow groundwaters are between 4.02 TU and 5.96 TU in the wet period and between 3.25 TU and 5.15 TU in the dry period. These tritium values are in the 


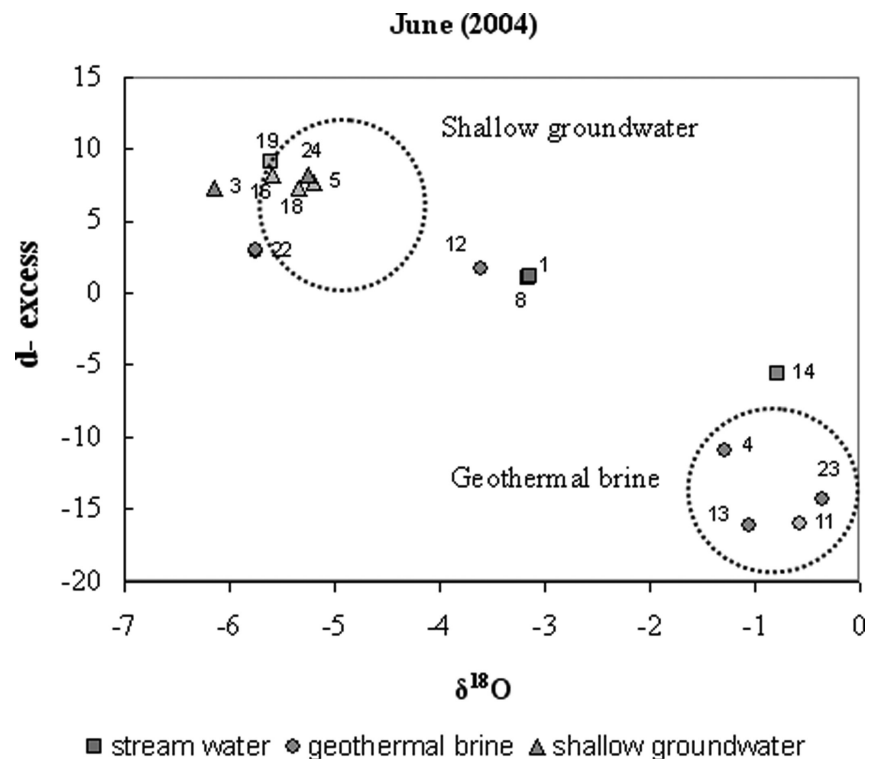

Figure 14. d-excess vs. $\delta^{18} \mathrm{O}$ plot showing relationship between evaporation and permeability features of waters.

range of annual mean values of precipitation (Global Network of Isotopes in Precipitation [GNIP]/IAEA Network). The residence times of shallow groundwater generally vary from several months to years (Mützenberg, 1997). In Tuzla Stream water, sample 1, the tritium value decreases from $3.55-0.55 \mathrm{TU}$ due to the contributions of geothermal brine free of tritium in the dry period. The tritium value of the cold-water spring (sample 3) near the geothermal brine manifestations is the same as that of the groundwater. Tritium data show a relative age of geothermal brine to be more than 50 years. Thus, the Tuzla hot brine seems to have a longer time of residence within the crystalline rocks. This result is consistent with the conclusions of Balderer and Synal $(1996 ; 1997)$ who calculated the mean residence time of the Tuzla brine as 430000 years by ${ }^{36} \mathrm{Cl} / \mathrm{Cl}$ ratio. In addition, the residence time of the Tuzla brine was also calculated to be as long as 1 million years by Mützenberg (1997). This confirms the hydrogeological conceptual model of Tuzla brine as coming from fossil pore-water, previously suggested by the studies (Balderer, 1997; Mützenberg, 1997).

\section{Conclusions}

The Tuzla geothermal brine, which has $\mathrm{NaCl}$ composition, discharges into the Tuzla Stream and spreads to the downstream area, consequently deteriorates the quality of shallow groundwater. The worsening in freshwater quality was investigated by chemical and isotopic tracers $\left(\delta^{18} \mathrm{O}, \delta \mathrm{D}\right.$, and tritium) in the area. Since the residence time of the shallow groundwater is relatively short (i.e. permeability of unsaturated zone is high enough for rapid infiltration) surficial salt accumulation can readily penetrate into the shallow aquifer in a short time. This observation is in good agreement with the findings of Mützenberg (1997). Thus, excessive enrichment of sodium in shallow groundwater leads to a decrease of soil permeability and drainage condition, eventually causing a salinity hazard.

The obtained results show that mainly two mechanisms may be hold responsible for the deterioration of shallow groundwater quality: 1) seasonal influx of salts and trace elements coming from the geothermal brine, which have accumulated at the surface; 2) direct mixing of geothermal brine with shallow groundwater via vertical faults and cracks. Due to these mechanisms, the stable isotope values of shallow groundwater are more positive than expected. However, the first mechanism seems to be more dominant due to the low temperature of shallow groundwater. Thus, the chemistry and isotope characteristics of the shallow groundwater are mainly controlled by the geothermal brine influence and halite dissolution on the surface of the soil that modifies surface water and groundwater quality. Therefore, the uncontrolled discharge from geothermal springs should be monitored and controlled to reduce its adverse effects.

\section{Acknowledgments}

This study has been funded by the Scientific and Technical Research Council of Turkey (TÜBİTAK) under project number 103Y010. We thank Ibrahim Aksu who checked the English of this article. The authors wish to thank Greg Whitmore for making suggestions to improve the manuscript and the valuable contributions of Serdar Bayari and Tolga Yalcin. Our special thanks to the anonymous reviewers for their help in editing of the manuscript.

\section{References}

Alpan, S. 1975. Geothermal energy exploration in Turkey. In 2nd United Nation Symposium on the Development and Use of Geothermal Resources, San Francisco, CA: USERDA and USGS, Washington.

Apello, T., and Postma, D. 1992. Geochemistry, groundwater and pollution 7(1): 18-19. Balkama Publishers, Rotterdam, Holland, 25-28.

Arnórsson, S., Gunnlaugsson, E., and Svavarsson, H. 1983. The chemistry of geothermal waters in Iceland. III. Chemical geothermometry in geothermal investigations. Geochimica et Cosmochimica Acta 47:567577.

Baba, A. 2003. Geothermal environmental impact assessment with special reference to the Tuzla Geothermal Area, Canakkale-Turkey. Geothermal Training Programme Book. Iceland: 75-114.

Baba, A., and Ozcan, H. 2004. Monitoring and evaluation of the geothermal fluid on soil and water in the Tuzla geothermal field by GIS. Remote Sensing and GIS for Environmental Studies. 113:138-143.

Baba, A., Ozcan, H., and Deniz, O. 2005. Environmental impact by spill of geothermal fluids at the geothermal field of Tuzla, Canakkale-Turkey. In Proceedings of the World Geothermal Congress 2005 (April 24-29, 2005, Antalya, Turkey), 1-8.

Baba, A., Deniz, O., Ozcan, H., Erees, S. F., and Cetiner, Z. 2007. Geochemical and radionuclide profile of Tuzla geothermal field, Turkey. Environmental Monitoring and Assessment 145, 1-3:361-374.

Balderer, W., and Synal, A. 1996. Application of the chlorine-36 method for the characterisation of the groundwater circulation in tectonically active areas: Examples from North Western Anatolia / Turkey. Terra Nova 824333.

Balderer, W. 1997. Mechanisms and processes of groundwater circulation in tectonically active areas. In Active Tectonic of Northwestern Anatolia 
- The Marmara Poly-Project, eds. Schindler, C., and Pfister, M. Zurich, Switzerland: vdf Hochschulverlag AG an der ETH, 375-415.

Balderer, W., and Synal, H. A. 1997. Use of chlorine-36 as tracer for the evolution of waters in geothermal and tectonic active areas in western turkey. Nuclear Instruments and Methods in Physics Research, B (NIMB) 123:387-393. Elsevier Science, B. V.

Craig, H. 1961. Isotopic variations in meteoric waters. Science 133:17021703.

Drever, I. 1997. The Geochemistry of Natural Waters, Surface and Groundwater Environments, 3rd ed. Saddle River, NJ: Prentice Hall, Upper, NJO7458, 164-178.

Ekingen, A .1972. Gravimetric survey of Ezine - Ayvacik - Bayramic surrounding, Ankara. MTA Report 4859.

Fournier, R. O., and Truesdell, A. H. 1973. An empirical Na-K-Ca geothermometer for natural waters. Geochimica et Cosmochimica Acta 37:12551275.

Fournier, R.O. 1979. A revised equation for the $\mathrm{Na} / \mathrm{K}$ geothermometer. Geothermal Resources Council Transactions 5:1-16.

Fournier, R. O., and Potter, R.W. II. 1982. An equation correlating the solubility of quartz in water from $25^{\circ} \mathrm{C}$ to $900^{\circ} \mathrm{C}$ at pressures up to 10,000 bars. Geochimica et Cosmochimica Acta 46(1969-1973).

Freeze, R. A., and Cherry, J. A. 1979. Groundwater. Englewood Cliffs, NJ: Prentice-Hall Inc.

Gevrek, A. I., and Sener, M. 1985. The determination of hydrothermal alteration zones by clay minerals in Canakkale-Tuzla area. In 2nd Turkish National Clay Symposium. Ankara, Turkey: Hacettepe University.

Giggenbach, W. F. 1988. Geothermal solute equilibria. Derivation of Na-KCa-Mg geoindicators. Geochimica et Cosmochimica Acta 52:2749-2765.

Giggenbach, W. F., Gonfiantini, R., Jangi, B. L., and Truesdell, A. H. 1983. Isotopic and chemical composition of Parbati Valley geothermal discharges, NW Himalaya, India. Geothermics 5:51-62.

Gledhill, D. K. 2005. Calcite Dissolution Kinetics and Solubility in NaCa-Mg-Cl Brines of Geologically Relevant Composition at 0.1 to $1 \mathrm{Bar}$ $\mathrm{PCO}_{2}$ And $25 \mathrm{To} 80^{\circ} \mathrm{C}$. Doctoral thesis, Eastern Connecticut State University and Texas A\&M University, 127.

Gupta, S. K., and Deshpande, R. D. 2005. Groundwater isotopic investigations in India: What has been learned? Current Science 89(5): 826-830.

Hoefs, J. 1987. Stable Isotope Geochemistry, 3rd ed. Munich, Germany: Springer Verlag.

(IAEA). 1981. Stable isotope hydrology. Technical Report Series 210: 339

Istvan, F., Toth, T., Palcsu, L., and Barna, G. 2006. Small isotope effect of evaporation when the rate of evaporation is very high: soil salinization on Nyiro-lapos (Hortobagy, Hungary). In International Workshop on Isotopic Effects in Evaporation, Extended Abstracts: Area della Ricerca CNR Pisa, Italy, 54-57.

Karamanderesi, I. H., and Ongur, T. 1974. The report of gradient wells Tuzla (Canakkale) geothermal field, Ankara. MTA Report 5524.

Karamanderesi, I. H. 1986. Hydrothermal alteration in well Tuzla T-2, Canakkale, Turkey. UNU-GTP, Iceland Report 3:36.

Kaszuba, J. P., Janecky, D. R., and Snow, M. G. 2003. Carbon dioxide reaction processes in a model brine aquifer at $2008 \mathrm{C}$ and 200 bars: Implications for geologic sequestration of carbon. Applied Geochemistry 18(7): 1065-1080.

Kaszuba, J. P., David T. J., and Snow, M. G. 2005. Experimental evaluation of mixed fluid reactions between supercritical carbon dioxide and $\mathrm{NaCl}$ brine: Relevance to the integrity of a geologic carbon repository. Chemical Geology 217:277-293.
Kehew, A. E. 2001. Applied Chemical Hydrogeology. New Jersey: Prentice Hall.

Keisuke, I. 1978. Ascending flow between the descending lithosphere and the overlying asthenosphere. Journal of Geophysical Research 83(B1): 262-268.

Kloppmann, W., Négrel, P., Casanova, J., Klinge, H,. Schelkes, K., and Guerrot, C. 2001. Halite dissolution derived brines in the vicinity of a Permian salt dome (N German Basin). Evidence from boron, strontium, oxygen, and hydrogen isotopes. Geochimica et Cosmochimica Acta 65(22): 4087-4101.

Ma, F., Yang, Y.S., Yuan, R., Cai, Z., and Pan, S. 2007. Study of shallow groundwater quality evolution under saline intrusion with environmental isotopes and geochemistry. Environmental Geology 51(6): 1009-1017.

Marini, L. Geochemical Techniques for the Exploration and Exploitation of Geothermal Energy.- Genova Italy: Univerisity degli Studi di Genova, Departimento per lo Studio del Territoria e della sue Risorse.

(MTA). 1997. 1/100 000 Scale-geological map, Biga Peninsula. Ankara, Turkey: General Directorate of Mineral Research and Exploration (MTA).

Mutlu, H., and Gulec, N. 1998. Hydrogeochemical outline of thermal waters and geothermometry applications in Anatolia (Turkey). Journal of Volcanology and Geothermal Research 85:495-515.

Mützenberg, S., Balderer, W., and Rauert, W. 1992. Environmental isotope study of saline geothermal systems in western Anatolia, Canakkale, Turkey. Water-Rock Interaction 2:1317-1320.

Mützenberg, S. 1997. Nature and origin of the thermal springs in the Tuzla area, Western Anatolia, Turkey. InActive Tectonic of Northwestern Anatolia - The Marmara Poly-Project, eds. Schindler, C., and Pfister, M. Zurich, Switzerland: vdf Hochschulverlag AG an der ETH, 301-317. Nicholson, K. 1993. Geothermal Fluids: Chemistry and Exploration Techniques. Berlin, Germany: Springer.

Samilgil, E. 1966. Hydrogeological report of geothermal energy possibility survey of hot springs of Kestanbol and Tuzla village of Canakkale. MTA Report 4274.

Samilgil, E. 1983. Geothermal fields in Canakkale and Tuzla drills. Turkish Geological Bulletin 4:147-148.

Stauffer, R. E., and Thompson, J. M. 1984. Arsenic and antimony in geothermal waters of Yellowstone N. Park, Wyoming, USA. Geochimica et Cosmochimica Acta 48:2547-2561.

Sener, M., and Gevrek, A, 2000. Distribution and significance of hydrothermal alteration minerals in the Tuzla hydrothermal system, Çanakkale, Turkey. Journal of Volcanology and Geothermal Research 96:215218.

Tarcan, G. 2005. Mineral saturation and scaling tendencies of waters discharged from wells $\left(>150^{\circ} \mathrm{C}\right)$ in geothermal areas of Turkey. Journal of Volcanology and Geothermal Research 142:263-283.

Urgun, S. 1971. The geology of Tuzla - Kestanbol (Canakkale) surrounding and geothermal energy possibility. MTA Report 4664.

Vengosh, A., Helvaci, C., and Karamanderesi, I. H. 2002. Geochemical constraints for origin of thermal waters from western Turkey. Applied Geochemistry 17:163-183.

Verhagen, B. T., Geyh, M. A., Fröhlich, K., and With, K. 1991. Isotope hydrological methods for the quantitative evaluation of groundwater resources in arid and semi-arid areas. Research Reports of the Federal Ministry for Economic Cooperation of the Federal Republic of Germany, Bonn, 7-122.

Yalcin, T. 2007. Geochemical characterization of the Biga Peninsula thermal waters (NW Turkey). Aquatic Geochemistry 13:75-93. 